No 2007 - 23

December

Labor Migration: Macroeonomic and demographic outlook for Europe and Neighborhood regions

Vladimir Borgy

Xavier Chojnicki 
Labor migration: macroeconomic and demographic outlook for Europe and neighborhood regions

\author{
Vladimir Borgy \\ Xavier Chojnicki
}

No $2007-23$

December 


\section{Contents}

\begin{tabular}{lll}
\hline 1 & Introduction & 8
\end{tabular}

$\begin{array}{lll}2 & \text { Demographics } & 10\end{array}$

2.1 Population structure and projection method . . . . . . . . . . . . . . . 12

2.2 Main demographic features of the baseline scenario . . . . . . . . . . . 13

3 INGENUE 2: A long term model for the world economy

3.1 Household behavior . . . . . . . . . . . . . . . . . . . . . 16

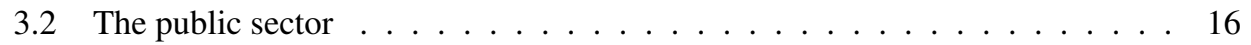

3.3 The production side and the world capital market $\ldots \ldots \ldots \ldots$. . . . . . 17

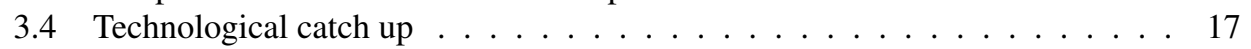

\begin{tabular}{|lll}
4 & Baseline path in the case without migration & 17
\end{tabular}

4.1 Solving the model $\ldots \ldots \ldots \ldots \ldots \ldots \ldots \ldots \ldots$

4.2 The world economy's baseline transition path $\ldots \ldots \ldots \ldots$

5 Consequences of migrations 22

5.1 Calibration of migration flows compatible with official figures . . . . . . 22

5.2 Results of the migration scenario $\ldots \ldots \ldots \ldots \ldots \ldots \ldots$

6 Conclusion 29 


\section{LABOR MIGRATION: MACROECONOMIC AND DEMOGRAPHIC OUTLOOK FOR EUROPE AND NEIGHBORHOOD REGIONS}

\section{SUMMARY}

Since the late 1990's, the pace of international migration has accelerated and this phenomenon is likely to further develop in the coming decades as part of globalization. The recent period is characterized by new migrations, especially from Eastern and Central European regions and Commonwealth of Independent States (CIS). The early period of transition was marked by ethnic and conflict-driven migration, while during the more recent one, migration became mainly economically-motivated. Since the frontiers of a larger Europe are not well-defined, it might be relevant to assess the consequences of tighter links between Western Europe and regions perceived to be in its back yard. The Neighborhood Policy of the European Union could define more precisely the migration policy between Europe and some specific countries. Some political leaders seem also ready to embrace the idea that an influx of migrants is the best way to save European pension systems by limiting the increase of the dependency ratio and the contribution rate.

In order to assess the demographic and economic consequences of migrations in Europe and neighborhood countries, we use the INGENUE 2 model. The model describes a multi-region, world model in which the structure of each regional economy is similar to that of other applied overlapping generations (OLG) general equilibrium models. In the model, the world is divided into ten regions according to geographical and demographic criterions. The GDP growth rate of each region relies mainly on its demographic evolution and on the assumption regarding the catching up process of total factor productivity. With this general equilibrium model, we have useful insights on the impact of the asynchronous ageing processes on international capital flows as well as the interest rates. The rich modeling framework of this multi-regions model allows us to put into connection migration with the "triangular" relationship between population aging, pension reforms and international capital markets that has received increasing attention in the academic literature.

Compared to other studies, our paper offers a global vision of the consequences of international migrations. Indeed, the value-added of the Ingenue model is that it is able to analyze the effects of international migrations on both the destination and the origin regions. The general equilibrium OLG model gives some interesting insights into the macroeconomic adjustments of such migration scenarios in the long run. In particular, we show that the financing of the PAYG pension system is noticeably improved in the regions receiving the migrants (Western Europe and the "Slavic world" in the migration scenario presented here). Nevertheless, one must note that a realistic migration scenario does not offset the effect of ageing in the regions receiving the migrants: in this regard, pension reforms appear to be necessary in order to deal with the ageing problem that these regions will face in a near future. Concerning the regions losing migrants, the adverse consequences of emigration are more important the more the region is advanced in the ageing process (and is already suffering from a declining population). In this regard, our analysis provides some quantitative results that allow us to compare the consequences of emigration for Eastern Europe and the "Mediterranean World", two regions that are not at the same stage in the ageing process. 


\begin{abstract}
In this paper, we assess the demographic and economic consequences of migrations in Europe and neighborhood countries. In order to do so, we rely on a multi-region world overlapping generations model (INGENUE2). The rich modeling framework of this multi-regions model allows us to put into connection migration with the "triangular" relationship between population aging, pension reforms and international capital markets. With this model, we are also able to quantify the demographic and economic consequences of migration flows on both the regions receiving and losing migrants. Our analysis is based on a very detailed migration scenario between Western Europe and the Neighborhood regions constructed by taking into account both the current situation and some prospective empirical scenarios. Our quantitative results shed some light on the long term consequences of migration on regions that are not at the same stage in the ageing process. Concerning the regions receiving migrants, despite some improvement of their public pension system, it appears that a realistic migration scenario does not offset the effect of ageing in these regions, leaving room for pension reforms. Concerning the regions losing migrants, the adverse economic consequences of emigration appear to be all the more important than the region is advanced in the ageing process (and is already suffering from a declining population).
\end{abstract}

JEL Classification: F21 - C68 - J61 - H55.

Keywords: CGEM, Migration, International capital flows, Neighborhood policy. 


\section{RÉSUMÉ}

MIGRATIONS DE TRAVAIL : CONSÉQUENCES DÉMOGRAPHIQUES ET MACROÉCONOMIQUES POUR L'EUROPE ET LES RÉGIONS DU VOISINAGE

Depuis la fin des années 90, le rythme des migrations internationales s'est accéléré et ce phénomène risque de s'accentuer encore dans les décennies à venir du fait du processus de mondialisation. Concernant l'Europe de l'Ouest, la période récente est caractérisée par de nouveaux flux migratoires, essentiellement en provenance de l'Europe de l'Est et des pays de l'ancien bloc soviétique. Ces nouveaux flux migratoires, qui ont trouvé leur origine dans des conflits politiques, s'expliquent plutôt, depuis tout récemment, par des motifs économiques. Etant donné que les frontières d'une Europe élargie ne sont pas bien définies, il paraît primordial d'évaluer les conséquences de liens plus étroits entre l'Union Européenne et les pays au voisinage de celle-ci. La politique de voisinage de l'Union Européenne se doit de définir de manière plus précise la politique migratoire de l'Europe envers ces pays. Dans le même temps un certain nombre de décideurs politiques se sentent également prêts à envisager l'éventualité d'un recours à l'immigration afin de limiter l'augmentation attendue du ratio de dépendance et des taux de cotisation aux systèmes de retraite.

Afin d'évaluer les conséquences démographiques et économiques des migrations pour l'Europe et les pays du voisinage, nous utilisons le modèle INGENUE2. Il s'agit d'un modèle mondial multi-régions dans lequel la structure de chaque économie régionale est similaire à celle des modèles appliqués traditionnels à générations imbriquées. Dans ce modèle, le monde est divisé en dix régions selon des critères géographiques et démographiques. Le taux de croissance du PIB de chaque région repose principalement sur les évolutions démographiques et les hypothèses relatives au rattrapage technologique. Ce modèle d'équilibre général calculable offre un aperçu utile de l'impact du processus de vieillissement asynchrone sur les flux de capitaux internationaux ainsi que sur les taux d'intérêt. Ce cadre d'analyse nous permet d'étudier l'impact des migrations sur la relation triangulaire entre vieillissement démographique, réformes des systèmes de retraite et marchés internationaux des capitaux, qui a reçu une attention toute particulière dans la littérature académique.

Par rapport aux autres travaux sur le sujet, ce papier offre une vision globale des conséquences des migrations internationales. En effet, le principal apport du modèle INGENUE2 est de permettre l'analyse des effets des migrations internationales à la fois pour les pays receveurs et les pays de départ. Ce modèle d'équilibre général calculable offre un aperçu intéressant des ajustements macroéconomiques de tels scénarii migratoires dans le long terme. En particulier, nous montrons que le financement des systèmes de retraite par répartition est sensiblement amélioré dans les régions d'accueil des migrants (en l'occurrence, l'Europe de l'Ouest et le "monde slave" dans le scénario migratoire présenté ici). Cependant, il convient de souligner que ce scénario migratoire réaliste n'annule pas pour autant les effets considérables découlant du vieillissement démographique. Ainsi, les réformes des systèmes de retraite s'avèrent plus que nécessaires pour faire face à ce phénomène dans un futur proche. S'agissant des régions de départ, les conséquences économiques des migrations sont inverses. Elles apparaissent d'autant plus fortes que la région est avancée dans le processus du vieillissement et d'ores et déjà touchée par une baisse de sa population. A cet égard, notre analyse fournit quelques résultats quantitatifs permettant de comparer les conséquences de l'émigration en Europe de l'Est et dans le "monde méditerranéen", deux régions se situant dans des phases différentes du processus de vieillissement de leur population. 


\section{RÉSUMÉ COURT}

L'ambition de cet article est d'évaluer les conséquences démographiques et macroéconomiques des migrations pour l'Europe et les régions au voisinage de celle-ci. A cette fin, nous utilisons un modèle multi-régions à générations imbriquées (INGENUE2). Ce cadre d'analyse nous permet d'étudier l'impact des migrations sur la relation triangulaire entre vieillissement démographique, réformes des systèmes de retraite et marchés internationaux des capitaux. Avec ce modèle, nous pouvons également quantifier les conséquences démographiques et économiques des flux migratoires à la fois pour les régions d'accueil et de départ. Notre analyse est basée sur un scénario migratoire très détaillé concernant l'Europe de l'Ouest et les régions au voisinage de celle-ci, construit en tenant compte de la situation actuelle et de quelques scénarii empiriques prospectifs. Notre analyse quantitative permet de mettre en avant les conséquences de long terme des migrations pour des régions ne se situant pas au même stade du processus de vieillissement démographique. Concernant les régions d'accueil, en dépit de quelques effets bénéfiques pour leur système de retraite, il apparaît que les migrations ne viendront pas contrebalancer les effets du vieillissement dans ces régions, laissant la question de la réforme des systèmes de retraite ouverte. Concernant les régions de départ, les conséquences économiques des migrations sont inverses et apparaissent d'autant plus fortes que la région est avancée dans le processus du vieillissement et se trouve d'ores et déjà touchée par une baisse de sa population.

Classification JEL : F21 - C68 - J61 - H55.

Mots-clé : MEGC, Migration, Flux de capitaux internationaux, Politique de voisinage. 


\title{
LABOR MIGRATION: MACROECONOMIC AND DEMOGRAPHIC OUTLOOK FOR EUROPE AND NEIGHBORHOOD REGIONS
}

\author{
Vladimir BORGY ${ }^{2}$ \\ Xavier CHOJNICK局
}

\section{Introduction}

For the past few years, the pace of international migration has accelerated and this phenomenon is likely to further develop in the coming decades as a part of the world globalization process. During the 20th century, Western Europe was one of the major host region of migrants with the United States. At the end of the last century, about 30 million foreigners were established there. Migration backgrounds are diverse but net immigration flows contribute significantly to population growth in Western Europe, in many cases overtaking natural population increases in recent years. Despite their recent status as immigration countries, Italy, Portugal, Spain and Greece continue to provide the largest foreign national stocks of emigrants. Turkey and Mediterranean countries complement the list of traditional origins of migrants to Western Europe.

The most recent period is characterized by new migrations, especially from Eastern and Central European regions and Commonwealth of Independent States (CIS). Indeed, migration flows between and within these regions have increased after the Soviet Union began to disintegrate. In the early 1990's, the annual number of officially recorded net migrants from Central and Eastern European countries to Western countries was around 850.000, more than twice the figure of the three preceding decades (Salt (2005)). The early period of transition was marked by ethnic and conflict-driven migration, while during the later, as the situation stabilized, migration became mainly economically motivated. In this respect, migration and associated policies became an important socio-economic issue both in receiving and in sending countries. As one of the main channels of interdependency among economies, immigration is a longstanding concern for policy-makers and has been alternately considered as a challenge or an opportunity for Western Europe.

Since the frontiers of a larger Europe are not well-defined, it might be relevant to assess the consequences of tighter links between Western Europe and regions perceived to be in its back yard. Such structural change is already in motion through the opening to larger flows of migrants from nearby territories. The Neighborhood Policy of the European Union could define more precisely the migration policy between Europe and some specific countries. Immigration is one policy option to alleviate the financial burden on the public retirement

\footnotetext{
${ }^{1}$ This paper is based on research carried out in the EU 6th framework funded research project "EU Eastern Neighborhood: Economic Potential and Future Development (ENEPO)". The authors gratefully acknowledge European Commission funding under the ENEPO project. This paper reflects the opinions of the authors and do not necessarily express the views of the institutions they belong to. We thank Frédéric Docquier and Abdeslam Marfouk for transmitting their dataset. We are grateful to Marek Dabrowski, Maryla Maliszewska, Toman Omar Mahmoud, Ainura Uzagalieva, Cyrille Schwellnus, Martine Carré and Agnès Bénassy-Quéré for useful comments and suggestions. The usual disclaimers apply. Correspondence: xavier.chojnicki@univ-lille2.fr

${ }^{2}$ Banque de France and CEPII (vladimir.borgy@banque-france.fr).

${ }^{3}$ CEPII and EQUIPPE, Universities of Lille (xavier.chojnicki@univ-lille2.fr).
} 
system and to sustain the growth rate of the working-age population. Some political leaders seem also ready to embrace the idea that an influx of migrants is the best way to save European pension systems by limiting the increase of the dependency ratio and of the contribution rate. Future trends in migration could have more substantial demographic consequences than what has been observed in the past. As fertility is now below replacement in Europe, policies to encourage immigration may become an important means for the EU to moderate rates of population decline. The European Union policy strategy on migration has been presented in several official publications (see European Commission (2006), for instance). The building of a common policy on labor immigration of the European Union is presented in detail by Carrera (2007). This question appears all the more crucial that numerous CIS countries (which constitute good candidates as emigration countries) are very advanced in the ageing process and are already suffering from a declining population.

In order to assess the demographic and economic consequences of migrations in Europe and neighborhood countries, we use the INGENUE 2 model ${ }^{4}$ The model describes a multiregion, world model in the spirit of those developed by Obstfeld \& Rogoff (1996) in which the structure of each regional economy is similar to that of other applied overlapping generations (OLG) general equilibrium models (such as Auerbach \& Kotlikoff (1987)). The INGENUE 2 model is presented in detail in a technical working paper (see Ingenue (2007a)) and several scenarios have been analyzed in detail by the INGENUE Team. Ingenue (2006) analyzed the consequences of sustained technological catching up in Eastern Europe as well as some specific migration scenario. Ingenue (2007b) detailed the global consequences of Asian regions catch up simultaneously with an improvement of the pensions systems in these regions.

In the model, the world is divided into ten regions according to geographical and demographic criteria. The GDP growth rate of each region relies mainly on its demographic evolution and on the assumption regarding the catching up process of total factor productivity. With this general equilibrium model, we have useful insights on the impact of the asynchronous ageing processes on international capital flows as well as the interest rates. We are also able to describe the demographic and economic consequences of migrations on both the regions receiving and losing migrants. Discussions on the macroeconomic effects of immigrations have become a focus of policy and media attention in Western Europe, following the surge in labor-force from new member states as well as neighborhood regions. To the best of our knowledge, very few works deal with this question using a general equilibrium applied approach.

The rich modeling framework of this multi-regions model allows us to put into connection migration with the "triangular" relationship between population aging, pension reforms and international capital markets that receives increasing attention in the academic literature, see Brooks (2003), Börsch-Supan, Ludwig \& Winter (2006), Aglietta et al. (2007) and Krueger \& Ludwig (2007). The purpose of this strand of the literature is to analyze the accumulation and the international flows of capital that are induced by the differential ageing process in different regions of the world.

Most of the existing theoretical and empirical literature on immigration is based on partial equilibrium models. Computable OLG models with migration usually consist of "closed" economy models. With the exception of the modeling of inflows of workers, the equilibrium of these OLG models is similar to the benchmark model of Auerbach \& Kotlikoff (1987). Storesletten (2000) and Chojnicki, Docquier \& Ragot (2005) investigate whether a reform

\footnotetext{
${ }^{4}$ The INGENUE 2 model was developed at CEPII, CEPREMAP and OFCE by Michel Aglietta (CEPII), Vladimir Borgy (CEPII), Jean Chateau (OECD), Michel Juillard (CEPREMAP), Jacques Le Cacheux (OFCE), Gilles Le Garrec (OFCE) and Vincent Touzé (OFCE).
} 
of immigration policies could attenuate the fiscal burden of ageing in the coming decades. Iakova (2007) and Barrell, FitzGerald \& Riley (2007) consider the macroeconomic effects of the migration that followed the enlargement of the EU in May 2004. Only two studies (Fehr, Jokisch \& Kotlikoff (2003, 2004)), have dealt with international migration in multicountry open-economy CGE-OLG models. These papers develop a three-country model (United States, Europe and Japan) to study the macroeconomic effects of increased immigration on the three countries' pension systems. Even if they use an open-economy framework, the impact of immigration on the sending countries and on inter-country inequalities are not treated as the regions losing the migrants are not explicitly modeled.

Compared to these studies, our paper offers a global vision of the consequences of international migrations. Indeed, the value-added of the Ingenue model is that it is able to analyze the effects of international migrations on both the destination and the origin regions. Consequently, the following questions are addressed: what is the impact of migration on economic growth, capital accumulation, consumption, pension schemes and the current accounts of sending and receiving countries? Can immigration from neighborhood regions help mitigate the adverse effects of population ageing in Western Europe?

We show that the financing of the PAYG pension system is noticeably improved in the regions receiving the migrants (Western Europe and the "Slavic world" in the migration scenario presented here). Nevertheless, one must note that this realistic migration scenario does not offset the effect of ageing in the regions receiving the migrants: in this regard, pension reforms appear to be necessary in order to deal with the ageing problem that these regions will face in a near future. Concerning the regions losing migrants, the adverse consequences of emigration are more important the more the region is advanced in the ageing process (and is already suffering from a declining population). In this regards, our analysis provides some quantitative results that allow us to compare the consequences of emigration for Eastern Europe and the "Mediterranean World", two regions that are not at the same stage in the ageing process.

The rest of the paper is organized as follows. Section 2 describes our demographic model. The macroeconomic model is presented in section 3 The main results of the baseline path (without migration) are presented in section 4 . The economic study of migrations from neighborhood countries follows in section 5 . Finally, section 6 concludes.

\section{Demographics}

The World is divided into ten regions according mainly to geographical and demographic criteria (Figure 1). These regions are labeled : Western Europe, Eastern Europe, North America, Latin America, Japan, "Mediterranean world", Eastern-Asian World, Africa, "Slavic World'5 and South-Asian World. The countries included in each region are detailed in Appendix 1. The neighborhood countries (CIS and Mediterranean countries) are included in 3 regions: the South Asian World (including Kazakhstan and Tajikistan), the "Slavic world" (including Russian Federation, Ukraine, Belarus and Republic of Moldova) and the ""Mediterranean world"" (including Armenia, Azerbaijan, Georgia, Kyrgyzstan, Turkmenistan, Uzbekistan, together with Maghreb and Middle-East countries).

\footnotetext{
${ }^{5}$ The countries included in the slavic area are more numerous than the ones included in this region of the model. The Slavic world of the model corresponds more precisely to the East Slavic area (with the exception of Moldova included in this region of the model).
} 


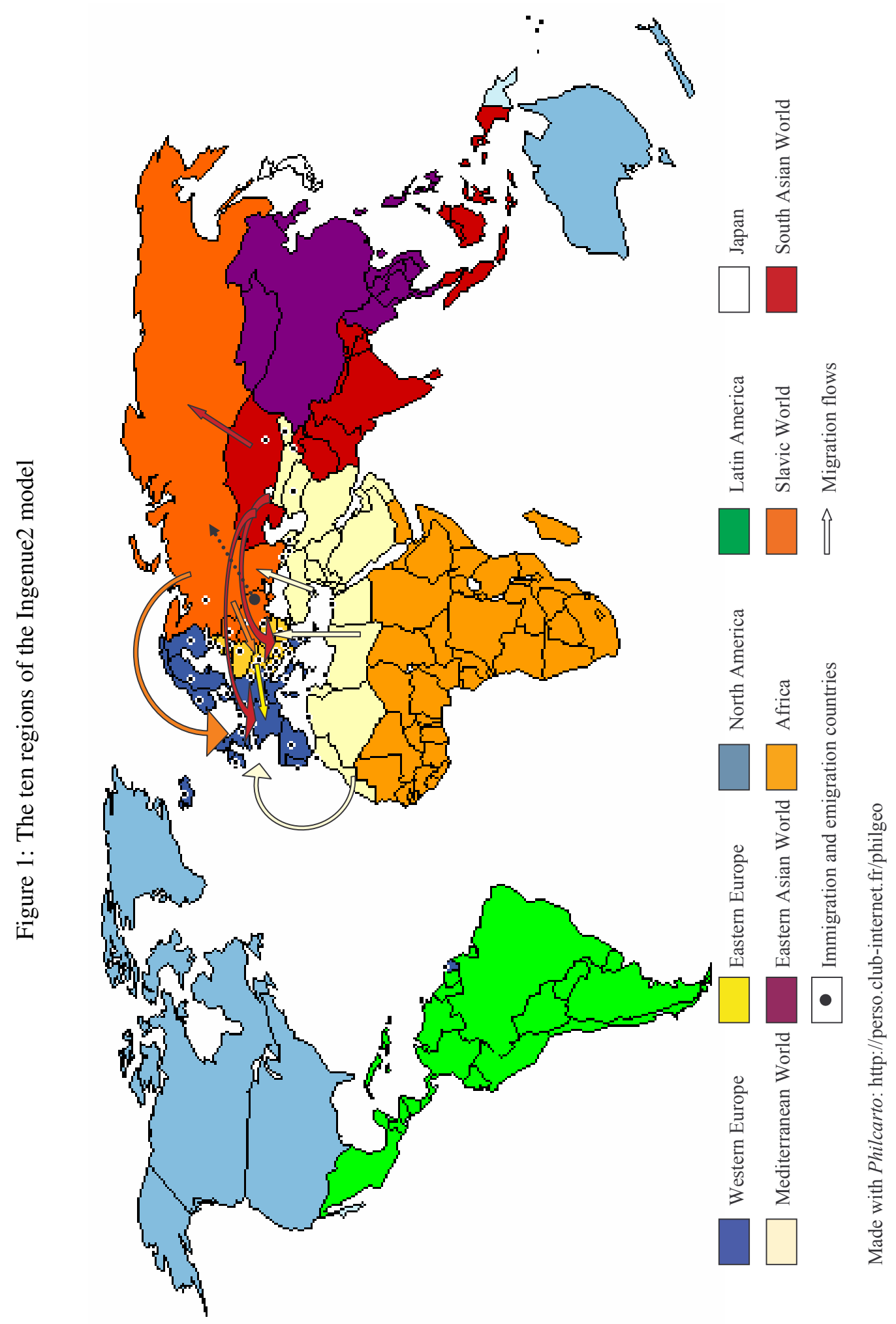




\subsection{Population structure and projection method}

The period of the model is set to five years. In each region $z$, the economy is populated by 21 overlapping generations who live up to a maximum age of 105. For notation purpose, age is denoted by $a \in[0, \ldots, 20]$. For instance, $a=2$ corresponds to the individuals aged 10-14. The number of people of age $a$ at time $t$ is: denoted by $L_{a}^{z}(t){ }^{6}$ At date $t$ the number of "births" (individuals between 0 and 4 years old) is then denoted by $L_{0}^{z}(t)$ and total population alive at time $t$ in Region $z$ is $L^{z}(t)=\sum_{a=0}^{20} L_{a}^{z}(t)$. Between ages 15 and 50, women give birth to children at the beginning of each period (Figure 2). Our agents die at each age and the probability of death is one at age 105 .

Figure 2: The individual life cycle

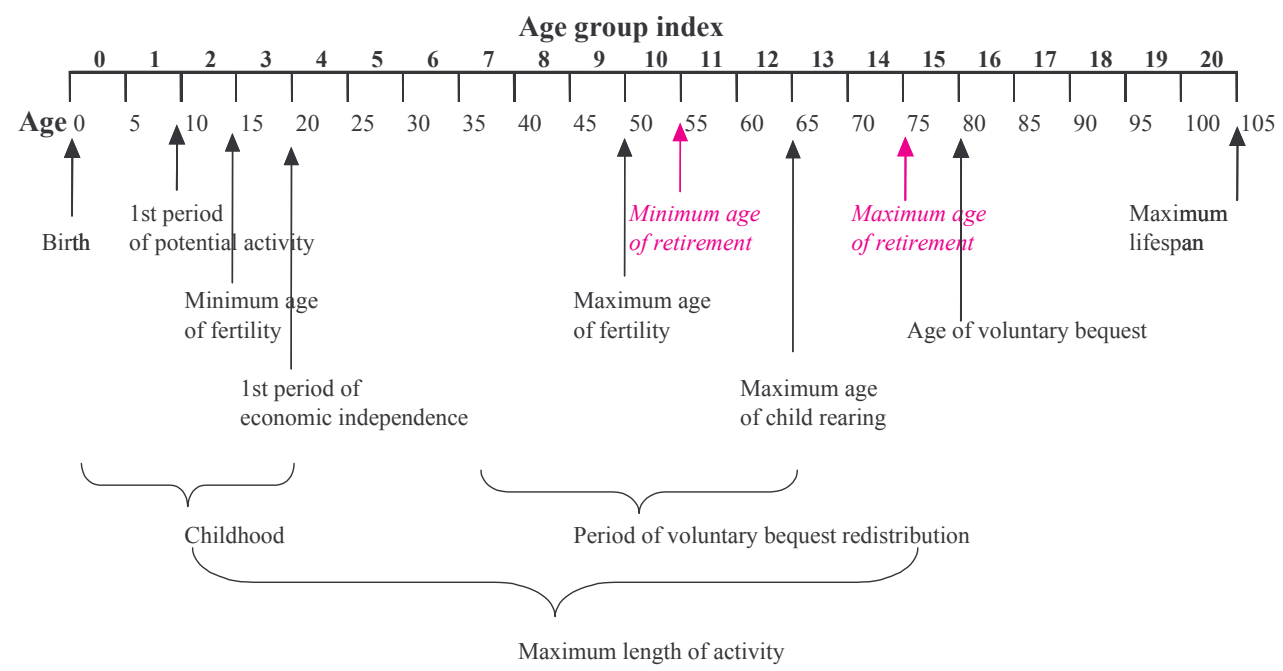

Population evolution is calculated according to a standard population projection method on the basis of historical and prospective UN data. For that purpose, a simple demographic model has been developed, allowing to generate projections that are consistent with UnitedNations (2001) data. First, we aggregate the population structure across the countries of each region with the UN data from 1950 to 1995. Then we project fertility, net migrations and mortality trends (for both sexes) at the region-aggregate level. This, together with initial population structures in 1995, allows us to obtain the evolution of the population at a world level from 2000 until the ending date of the model. With some usual population projection methods, the evolutions of mortality and fertility tables are constructed on the only basis of life expectancy and global fertility rates evolutions in the future.

At each time, the number of births is equal to:

$$
L_{0}^{z}(t)=\sum_{a=3}^{9} f_{a}^{z}(t) L_{f} a^{z}(t)
$$

where $L_{f} a^{z}(t)$ is the female population of age $a$ at time $t$ and $f_{a}^{z}$ is the average age-specific

\footnotetext{
${ }^{6}$ More generally, for any household variable, a subscript $a$ denotes age and an argument $t$ in parentheses denotes calendar time.
} 
fertility rate. At each time, we calibrate $f_{a}^{z}$ for the ten geographic regions so that the number of births matches the UN figures until 2050.

Individuals can die before 105 years old with $s_{a}$ denoting the conditional probability of surviving between age $a$ and age $a+1$, the number of age $a$ individuals then follows :

$$
L_{a}^{z}(t)=s_{a-1}^{z}(t-1) \cdot L_{a-1}^{z}(t-1)+\sum_{z *} M_{a}^{z *}(t) \quad \text { for all } a>0
$$

with $M_{a}^{z *}(t)$ the number of net migrants of age $a$ that enter or leave the country at time $t$. We thus have $M_{a}^{z *}(t)>0$ in case of immigration and $M_{a}^{z *}(t)<0$ in case of emigration.

For population projections, we then need some process to describe the evolution of $\left\{s_{a-1}^{z}(t-\right.$ 1) $\}_{a>0}$ for $t=2000, \ldots, T$ (for both genders). For this, we first have to set initial and final mortality tables. The starting tables are taken from UN data between years 1995 and 2000. The ending table are chosen among UN "typical" long run mortality tables (from Coale \& Demeny (1966)). According to UN methods, we extrapolate future mortality tables on the basis of an expected trend for life expectancy. We adopt a linear process of convergence.

In the baseline scenario, we implicitly assume that there is no migration flows in the future $\left(M_{a}^{z *}(t)=0\right)$ so that the population evolution is only given by mortality and fertility assumptions. Our baseline population projection thus corresponds to the UN variant with no migration flows (United-Nations (2001)). Then, we build a comprehensive migratory scenario to analyze the demographic and economic consequences of migration for Europe and the neighborhood regions. Unlike fertility and mortality, which are in transition worldwide from high to low levels in a long historical process, there is much more uncertainty concerning net migration (see Alho \& Borgy (2007)). Therefore, migration projections have no strong and consistent trend that can serve as the backbone of credible projection assumptions for the future, particularly in the case of Eastern Europe and CIS countries that had recently known crisis migration. For this reason, it is important to assess migration potential of these regions by analyzing the main driving forces of the past and recent trends. For that purpose, we use the migration estimation run by Uzagalieva (2007). Assumptions related to migratory flows are then developed in details in section 5

After 2050, the demographic model is calibrated in order for the population to converge towards a stationary level, which is a technical constraint to satisfy in order to compute the steady state of the OLG model. For that purpose, the number of females entering the population must be equal to the number of outgoing females, i.e. to the number of deaths. Indeed, when the number of women is constant, the number of births is constant and the model converges automatically towards a stationary population.

\subsection{Main demographic features of the baseline scenario}

Our baseline scenario reproduces UN projections with no migration through 2050. According to our demographic forecasts, the world population reaches 9.3 billions in 2050 and 10.3 billions in $2100[7$ Population of the South Asian world grows at a sustained pace and reaches $31 \%$ of the world population in 2050 against $28.3 \%$ in 2000 (see Figure 3(a). Population of the Eastern Asian world increases at a very low pace between 2030 and its culmination in 2050. As a consequence, the share of the population of this region decreases during the first part of the 21 st century (from $27 \%$ to $22 \%$ ). The population of the African region is growing at the highest pace in our projections given the high fertility rates that characterize the countries included in this region. The Mediterranean region is also characterized by a

\footnotetext{
${ }^{7}$ The historical data (between 1950 and 2000) come from the UN database.
} 
dynamic demography with a doubling population on the first half of the century. On the contrary, the Western European population is relatively stable until 2020 and then clearly diminishes. This figure is even more pronounced for Eastern Europe and the "Slavic world" with a total population that starts to shrink immediately (respectively $-15 \%$ and $-30 \%$ between 2000 and 2050).

A sharp contrast arises with the rate of growth of the labor-force (Figure 3(b)). Without migrations, it declines throughout the first half century in the "Slavic world" (very fast), Eastern Europe, Western Europe and Japan. It declines more moderately in North America (after 2010) and the Eastern Asian world (after 2020). It decelerates but grows until 2050 in Latin America, South Asia and the Mediterranean countries. The most atypical region is Africa where the labor-force hardly decelerates at all. As a consequence of the dynamism of their working-age population, these regions need a lot of capital to equip their numerous workers. As the leading OECD countries concentrate the largest part of world capital, the growth regime will depend on international capital but also, to a lower extent, on labor mobility. An intergenerational transfer of resources via capital export from the rich ageing countries to the labor-force growing countries will make the world regions strongly interdependent.

Indeed, this generalized but differentiated ageing process is occurring in a world of increasing capital mobility and financial globalization. This suggests that it may give rise to new opportunities for profitable exchanges amongst regions. One can see on Figure 3(c) that the proportion of high savers in total population follows a wave pattern that propagates from one region of the world to the next through the decades 8 The ratio culminates first in Japan as soon as 1995 and remains at a high level until 2030. Then, North America experiences its maximum in 2025 and Western Europe in 2030, Eastern Europe, Slavic and Eastern Asian world after this date. All are regions with declining labor-force and thus hamper growth in the future. On the contrary, the regions found on Figure 3(b) as the potentially fast-growing regions see a progressive ageing leading to an increase of the high savers ratio which does not culminate before 2050. It follows that savings will likely flow from early high savers to late high savers in the coming decades.

Finally, this ageing phenomenon is summed up on Figure $3(\mathrm{~d})$ that presents the evolution of the old age dependency ratio (retirees in percentage of total working-age population). While the fact of population ageing is common to all regions (except Africa), extent and timing differ substantially. For example, this ratio is doubling in the case of Western Europe on the first half of the XXIst century and is expected to be almost $100 \%$ in 2050 whereas it is expected to be only around $43 \%$ in the same time in the "Mediterranean world". It should be noted that Eastern Europe and the "Slavic world" are more severely affected by ageing. The resulting asynchronous demographic ageing raises numerous issues for pension schemes concerning notably replacement migrations. Indeed, developed countries have an incentive to increase legal immigration since this would alleviate the financial burden on the public retirement system by limiting the increase of the dependency ratio and the contribution rate.

\footnotetext{
${ }^{8}$ In this OLG model with life cycle behavior, the high saver populations are the cohorts aged between 45 and 69 years.
} 

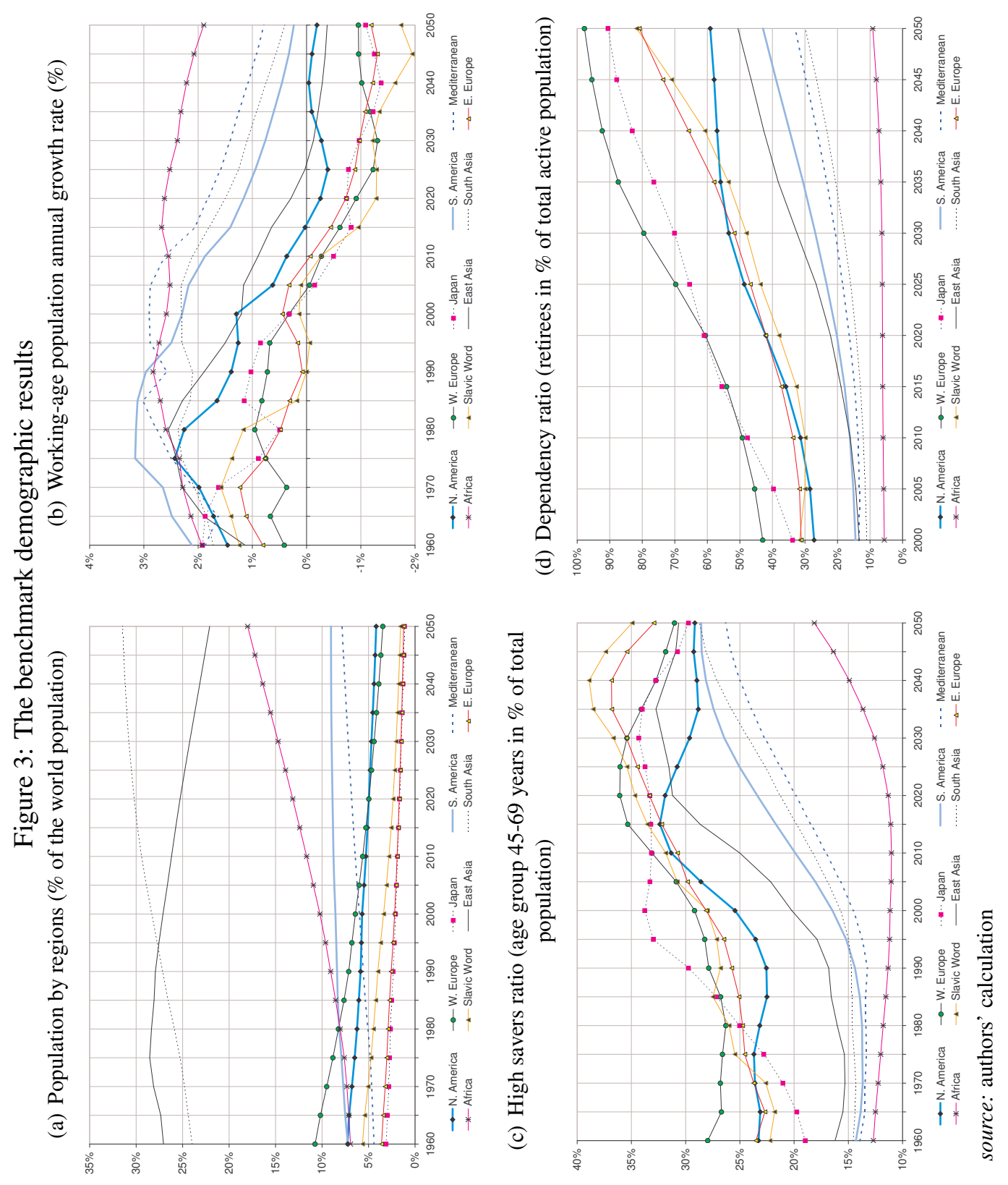


\section{INGENUE 2: A long term model for the world economy}

Our economic simulations were made with the computable, general equilibrium, multi-regional overlapping-generations model INGENUE $29^{9}$ The model was initially constructed to assess wealth accumulation and the development of pension funds and other forms of retirement saving, in a global macroeconomic setting, for ten major regions of the world, until 2050. For a synthetic view on global demographic changes, see IMF (2004) and Ingenue (2002). This issue is also explored in a multi-country model by Börsch-Supan et al. (2006) and Krueger \& Ludwig (2007). Each region is made of four categories of economic agents : the households, the firms, a fictive world producer of a world intermediate good and a Pay As You Go (PAYG) retirement pension system $\sqrt{10}$

\subsection{Household behavior}

The individual life-cycle of a representative agent is described in Figure 2. Between ages 0 and 20, the representative agent is a child and is supported by her parents. Given the specificities of developing countries, we assume that children can begin to work at age 10 but their income is included in their parent income. At age 21, the representative agent becomes independent and starts working. When becoming independent, individuals make economic decisions according to the life cycle hypothesis. A voluntary bequest is left to children at age 80 subject to survival until 80 .

In the budget constraint (see Equation 3 in Appendix 2), the expenditures consist of consumption (including costs of children) and saving in each age and each period. On the income side there is, first, the return on accumulated saving corrected by one-period survival probabilities. Second, there is non-financial income that depends on age: labor income (after social security contributions) adjusted by a region-specific age profile of labor-force participation for people in full labor activity; a mix of labor income and pension benefits for people partially retired (reduced labor activity); full pension benefits for people entirely retired. The lifetime utility (Equation 2) is maximized under the intertemporal budget constraint, taking prices, social contributions and benefits as given (Modigliani (1986)). Like Fehr, Jokisch \& Kotlikoff (2004), we do not distinguish between natives and immigrants in the model once the migrants have joined the destination country.

\subsection{The public sector}

The public sector is reduced to a social security department. It is a Pay-As-You-Go (PAYG) public pension scheme, that is supposed to exist in all regions of the world. It is financed by a payroll tax on all labor incomes and pays pensions to retired households. The regional PAYG systems operate according to a defined-benefit rule. The exogenous parameters are the retirement age and the replacement ratio. They are region-specific and the contribution rate is determined so as to balance the budget, period by period (Equation 5.

\footnotetext{
${ }^{9}$ For technical features of the new INGENUE 2 model, as well as the baseline scenario and a sensitivity analysis of the main structural parameters, see Ingenue (2007a).

${ }^{10}$ This presentation of the multi-regions model is completed by the technical appendix. The equations mentioned in this section are presented in detail in Appendix 2.
} 


\subsection{The production side and the world capital market}

In order to deal with relative price movements of foreign and domestic goods we assume that the different countries produce different, imperfectly substitutable intermediate goods using labor and capital (Equation 6). In the spirit of Backus, Kehoe \& Kydland (1995), we assume that the domestic composite final good of each region is produced according to a combination of the domestic intermediate good and an homogenous world good imported by the region from a world market (Equation 9). In order to simplify the exchanges of intermediate goods between regions of the world, this homogenous world good is "produced" by a fictive world producer as the output of a combination of all intermediate goods exported by the regions (Equation 10).

The depreciation rate is asymmetrically dependent on the ownership ratio, defined as the ratio of the total wealth of households to the capital stock (see Equation 12). Indeed, firms located in countries that are indebted to the rest of the world borrow at a higher interest rate than the world interest rate and this "indebtedness premium" is proportional to its financial market exposure (measured by the ownership ratio). At equilibrium, the marginal return to capital thus depends on the net external position. In net debtor regions (ownership ratio less than one), the imperfection of international financial markets raises the cost of capital. It shows up in a higher rate of depreciation of the capital stock. In net creditor regions (ownership ratio above one), the rate of depreciation is a constant, thus independent from the financial position.

\subsection{Technological catch up}

All production functions are augmented by Total Factor Productivity (TFP) coefficients at constant prices. Estimating TFP for the ten world regions of the INGENUE 2 model is a very difficult task. We define TFP as a Hicksian neutral technological progress in a Solow growth model. It means that there exits a production frontier shifting over time. The level of TFP is exogenous and grows at a constant rate, in each region. For 1950 until 2000, the growth rate of TFP is given by historical data (see Heston, Summers \& Aten (2002)). After this date the rate of growth of the TFP is the result of a given, exogenous growth of $1.1 \%$ per annum in the North American region, supposed to be the technological leader, and a region-specific exogenous, catching-up factor, reflecting international diffusion of technological progress. In the baseline scenario of the model, three regions have a sustained catch up process: the takeoff in the Eastern Asian and South Asian regions which started in the 1990's is assumed to gain momentum. Eastern Europe is also assumed to be a fast-growing region due to its participation to the European Union. Figure 4 gathers the profiles of TFP in the world regions of the INGENUE 2 model. Before 2000, the model has been calibrated on the basis of the international macroeconomic database constructed by Heston et al. (2002).

\section{Baseline path in the case without migration}

\subsection{Solving the model}

The baseline scenario is the outcome of a long and weary process of calibration. To put the model on an acceptable track on the projection phase starting in 2000 , the model computation shall begin at an initial date as far as in the past as the data permit it. The initialization begins in 1950 where initial stock of capital, household assets and an age distribution of savings are estimated. Exogenous variables and parameters in each region include the demographic 
Figure 4: Total Factor Productivity: 1950-2100 (\% of North America level)

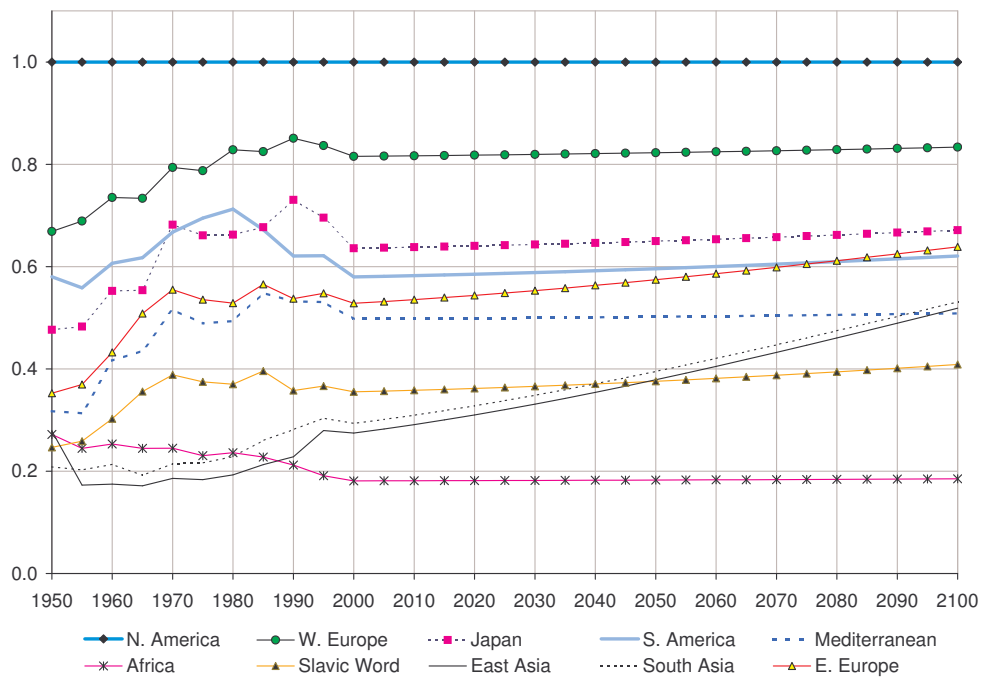

profiles (that are outputs of the upstream demographic model); the coefficients of TFP catch up; and the social security policy parameters.

The competitive world equilibrium stems from five sets of equations: intertemporal utility maximization of households; intertemporal profit maximization of firms in intermediate goods sectors; period profit maximization of firms in final goods sectors; period profit maximization of the world producer; and market clearing conditions. The markets for intermediate goods, final goods, labor in each region, and the market for the world intermediate good, are cleared in each period. These equations determine all relative equilibrium prices expressed in a common numeraire, which is the price of the intermediate good in North America. This convention allows us to express values in constant dollars. Finally, the Walras law implies that the world financial market equilibrium is the redundant equation.

\subsection{The world economy's baseline transition path}

We now turn to our simulated baseline policy transition paths for the ten regions. The baseline scenario is not easy to depict since it is a dynamic rational expectations general equilibrium model. Any order of description is somewhat arbitrary because it could give the false impression of a recursive causal system of determination between blocks of relations. Here, we only try to give the main intuitions necessary to understand how the model works (see Ingenue (2007a, 2007b) for a complete description of the baseline). Results of the migration scenario will be presented with more details.

\section{Regional growth}

Growth in the world economy is shaped by secular trends in its most structural long-run determinants, i.e. the change in the demographic structure in the different parts of the world and the diffusion of technological progress. As previously detailed, assumptions regarding technological convergence are conservative in the baseline scenario. Besides, the parameters that define public pension systems perpetuate existing policies in the beginning of the XXIst 
century. Therefore the pattern of the GDP regional growth rates largely follows that of the regional labor-force growth rates.

Two characteristics stand out (see Figure 5(a) $)$. Firstly, there is a general slowdown in growth because the working-age population growth rate diminishes in all regions except Africa after 2000. Secondly, the dispersion in growth rates is almost as large in 2050 as in 2000, because ageing is a lengthy process with countervailing impacts on the labor-force of less-developed countries. Nevertheless convergence in total factor productivity has an impact since the dispersion in the growth rates of the labor-force is substantially higher in 2050 than in 2000 compared to the dispersion in the GDP growth rates.

North America and Europe have growth profiles that partly differ from the general pattern. In North America, growth decelerates precipitously in the first decade after 2000 and stabilizes thereafter, following the labor-force and productivity pattern. Europe (West and East) and worse the "Slavic world" have a gloomy future. Western Europe follows a similar profile as North America but at much lower growth rates. GDP growth decelerates fast after 2000 until 2030 from 3.2 to $0.7 \%$ and stabilizes until 2050. The "Slavic world" is the region with the lowest growth rate almost throughout the half-century and ends up in complete stagnation.

\section{Investment and saving}

Gross investment rises with net capital accumulation and with replacement, which is modulated by the change in the rate of depreciation in debtor regions. Therefore in regions with a fast growth of the labor-force and high foreign indebtedness, the ratio of gross investment to GDP increases until 2030.

Net saving in each region is the aggregate of individual savings over the life cycle. It depends on the demographic structure (high savers ratio and dependency ratio), on the expectation of future income and on the parameters of PAYG pension systems. Demographic determinants are prevalent. Regions with the fastest-increasing dependency ratios are the ones with the fastest-decreasing net saving rates, namely Japan, Western Europe, Eastern Europe, "Slavic world" (Figure $5(\mathrm{~b})$ ). Meanwhile, this gloomy demographic factor is compounded with a slow expected progression in income. In the Eastern Asian, South Asian, South American and Mediterranean regions, the high saver ratio and the dependency ratio rise in tandem until 2050. Indeed, ageing in these countries is explained more by a deceleration in the workingage population growth than by an increase in the number of retirees. In the early decades, while the population is still young, those regions grow faster than more demographically mature ones. It follows that young people (those aged between 21 and 25) are expecting higher future income indulge in debt, reducing the overall saving rate.

\section{Interest rates and capital flows}

According to the model, the world real interest rate declines over the fifty years period. This is due to global ageing. Figures 3(b) and 3(c) show that the working-age population simultaneously decelerates or declines in all regions while the age group of high savers grows in one region after another. As a result, the world saving-investment balance is tilted more and more towards a lower interest rate. This downward trend provides the general profile of regional real interest rates (see Figure 5(c)). The hierarchy of regional real interest rates is linked to the rate of change of the real exchange rates which regulate investment and saving flows. The gap between investment and saving is the current account balance of each region. It is financed by capital flows whose amounts are such that yield differentials between different regions cancel out in every period. 
The world financial equilibrium allocates capital flows so as to finance current account imbalances. The magnitude of financial positions is measured by the ownership ratio which is the ratio of the aggregate wealth accumulated by households in the region to the capital stock laid out in the region. Hence a ratio above one is tantamount to a creditor position against the rest of the world, a ratio less than one to a debtor position. The ownership ratios are determined by cumulative current account balances. The most striking feature is the divergent profile of North America (see Figure 5(d)). It is due to an assumed change in household saving behavior. With this structural change and with a population consistently younger than in Japan and Europe, the rise in saving in North America is translated into a double improvement in the current account balance and the ownership ratio. 


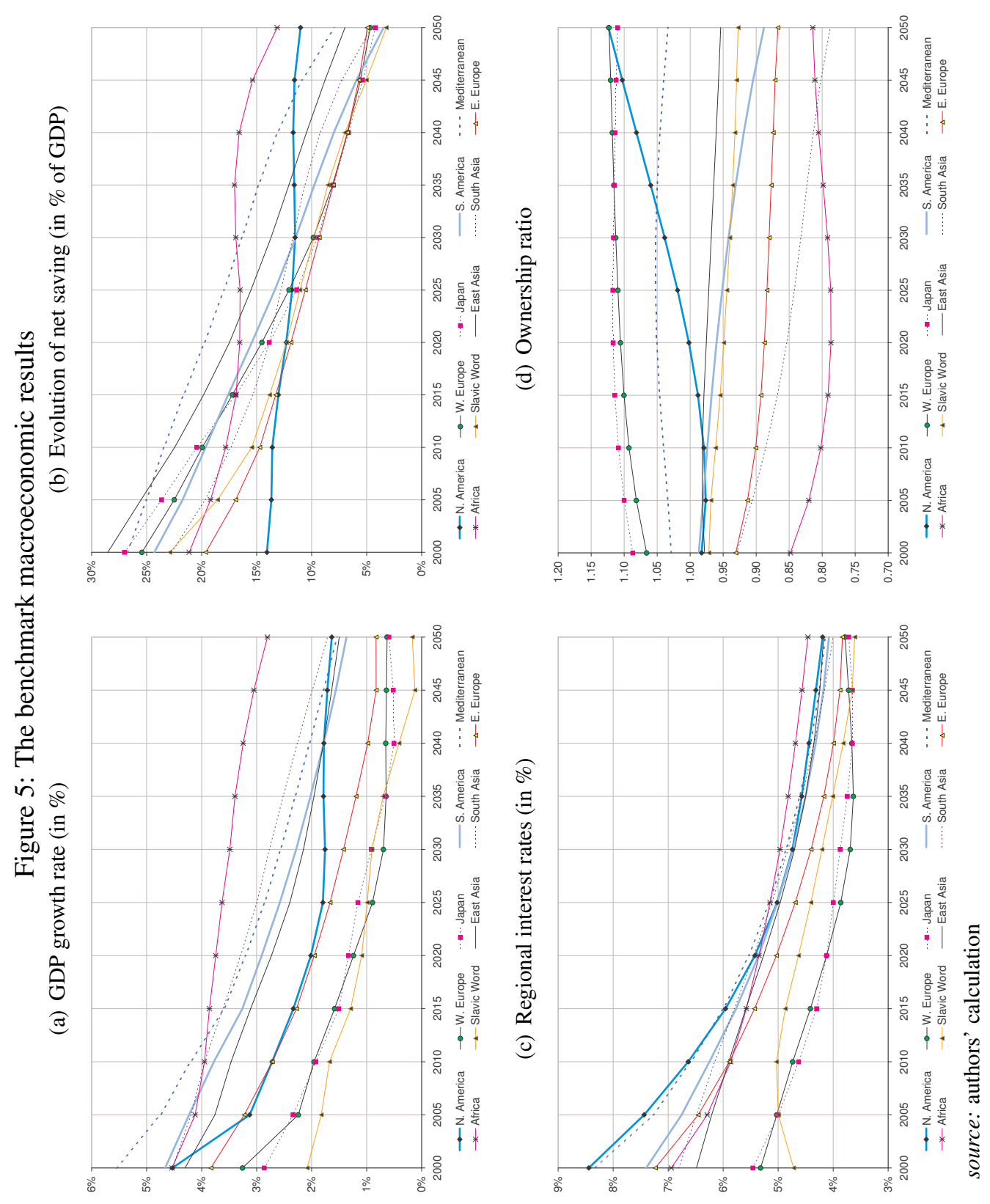




\section{Consequences of migrations}

We now turn to the demographic and economic consequences of migrations from neighborhood countries into the European Union. For that purpose, an immigration shock is introduced in the model as an increase in the number of young adults (aged between 21 and 24, i.e. $M_{a}^{z *}(t)=0$ if $a \neq 4$ ). After crossing the border, immigrants automatically become natives in an economic sense, i.e. they have the same preferences and fertility behaviors as natives and adjust to the productivity of the host region. Furthermore, as in Storesletten (2000), we assume that immigrants move into receiving countries without any capital (note that natives have no wealth at the same age) ${ }^{11}$ However, this choice seems to play a minor part in the results since most immigrants actually enter the country before the age of 30 , i.e. at the beginning of the wealth accumulation process.

\subsection{Calibration of migration flows compatible with official figures}

Given the regional grouping of the INGENUE2 model, the neighborhood regions are included in three regions of the model: the "Slavic world", the South Asian world and the "Mediterranean world". For the South Asian world, we only calibrate migration flows for the two CIS countries that are included in this region: Kazakhstan and Tajikistan. For the "Mediterranean world", we distinguish migration flows from North Africa (Algeria, Egypt, Libya, Morocco, Tunisia and Western Sahara) and from the CIS Middle East countries (Armenia, Azerbaijan, Georgia, Kyrgyzstan, Turkmenistan and Uzbekistan). The "Slavic world" is composed of the Russian Federation, Ukraine, Belarus and Moldova.

\section{Evaluation of current migration flows}

International migrants are unevenly distributed across world regions. By $2005,47 \%$ of the stock of international migrants were resident in industrial countries and 53\% in developing countries. Here we only focus on migrations that concern Europe and CIS regions. Western Europe has experienced net inflows of migration for four decades and represents the second major immigration area with $21 \%$ of the total immigrant stock (United-Nations (2004)). Eastern Europe and the former Soviet Union have a stock of migrants of around $15 \%$ of total stock. Migration in these regions follow a broad biaxial pattern: on one axis a migration system developed among the countries of Western, Central and Eastern Europe and on the other a system of movement arose among the CIS countries (World Bank (2006)). For example, Russia receives $75 \%$ of its immigrants from other CIS countries and over $70 \%$ of migrants from Western ECA (Europe and Central Asia regions) go to Western Europe (World Bank (2006)). Finally, North Africa is characterized by a predominant labor migration toward Europe.

Following these facts, we distinguish four types of regions in the model:

- pure immigration zones only face inward flows: Western Europe;

- pure emigration zones only face outward flows: "Mediterranean world", South Asian World;

- intermediate zones face simultaneously in- and outflows: Eastern Europe, "Slavic world";

\footnotetext{
${ }^{11}$ These assumptions are necessary to avoid problems of agent heterogeneity that would complicate the computation of the transitory path.
} 
- no migration zones are isolated from international mobility of workers (there is thus neither immigration nor emigration): North America, Latin America, Eastern Asian World, Africa. This assumption is necessary given by the fact that we focus on neighborhood regions' migration flows.

We then adopt a calibration process that allows to make actual net migration flows compatible with our multi-regions description of the world using different data sources. First, we aggregate net migration flows by countries used in the medium variant of 2004 UN population projections (United-Nations (2004)) to correspond to the INGENUE2 regional grouping. Then, we calibrate immigration flows to Western Europe, Eastern Europe and the "Slavic world" on UN figures removing intra-regional flows (for example German migrations to France) as well as non-pertinent flows (for instance Western Europe migrations to North America). Given the world aspect of our model, immigration in host regions has to correspond to emigration in sending regions. Thus, we have to allocate immigration flows to Western Europe, Eastern Europe and the "Slavic world" by origin regions. For that purpose, we first use the emigration stocks and rates of 195 origin countries built by Docquier \& Marfouk (2005) to allocate the immigration flows to Western Europe between our pure emigration zones.

However, Docquier \& Marfouk (2005)'s database only focus on OECD countries as receiving countries and there is no information on migration flows to Eastern Europe and the "Slavic world". Thus, for Eastern Europe, the "Slavic world" and the CIS countries, we complete with the recent World Bank report on Eastern Europe and the former Soviet Union (World Bank (2006)) as well as with the recent data of Salt (2005). Table 1 gives the calibrated net migration flows by regions in 2005 and Figure 1 gives the direction of migration flows by region as well as countries concerned by migration. Note that the calibrated flows appear lower than the UN official net flows given that we only focus on Western Europe and neighborhood regions.

Table 1: Yearly net migration flows by origin and destination countries in 2005 (in thousand)

\begin{tabular}{|c|c|c|c|c|c|}
\hline & & \multicolumn{3}{|c|}{ Destination Countries } & \multirow[b]{2}{*}{ Total Emigration } \\
\hline & & Western Europe & Eastern Europe & Slavic World & \\
\hline \multirow{8}{*}{ 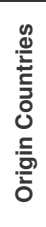 } & Mediterranean World & 124.6 & 0.8 & 53.2 & 178.6 \\
\hline & - North Africa & 112.9 & 0.5 & 0.0 & 113.3 \\
\hline & - CIS Middle East Countries & 11.7 & 0.4 & 53.2 & 65.3 \\
\hline & South Asian World & 9.8 & 0.2 & 54.6 & 64.7 \\
\hline & Eastern Europe & 74.6 & 0.0 & 0.0 & 74.6 \\
\hline & Slavic World & 47.1 & 23.7 & 18.2 & 89.0 \\
\hline & - Russian Federation & 29.6 & 5.0 & 0.0 & 34.6 \\
\hline & - Ukraine & 17.5 & 18.7 & 18.2 & 54.4 \\
\hline & Total Immigration & 256.1 & 24.7 & 126.0 & 406.9 \\
\hline
\end{tabular}

\section{Estimation of future migration flows}

We have to reproduce this methodology for each five-year period in the future. Some migration streams are durable, lasting decades, and relatively predictable. Conversely, assessing migration potential in CIS countries is a very complex task requiring a careful consideration of factors, apart from economic and demographic ones. Indeed, the recent study of the World Bank (2006) suggests that the nature of labor migration in the CIS countries has changed since the beginning of the reforms. Namely, emigration from these countries was caused primarily by political and ethnic motives, initially. In recent years, economic reasons have become increasingly important and workers move mainly for higher incomes, better job opportunities 
and quality of life. Moreover, migration flows that have been observed in the recent period may be unsustainable in a decade owing to the medium-term population dynamics in most of the CIS countries. Consequently, future migrations flows from CIS countries can not be evaluated by simply extending recent flows. The main driving forces of the past and recent trends in the migration flows in CIS thus have to be fully analyzed.

For these reasons, we use the estimations performed by Uzagalieva (2007) concerning possible scenarios of future migration flows in CIS countries until 2025. Uzagalieva (2007) evaluates potential migration flows from CIS to Western Europe and Russia based on economic and demographic factors but also on other factors of migrants' life such as ethnic background, political situation and migration policies in CIS countries. The assessment of the immigration potential to Russia and Western Europe from CIS countries also requires a number of assumptions to be made in order to reflect future differences in economic and political climate, policies and reform progress. More specifically, among the different scenarios suggested by Uzagalieva (2007), we adopt the status-quo scenario in terms of catching-up which is close to our assumptions on TFP.

In concrete terms, the scenarios of future migration flows in CIS countries are determined for three population groups separately:

1. The first group includes emigration for ethnic reasons (nationalities which have ethnic ties with other countries) that will most likely emigrate irrespective of socio-economic and political situation in CIS, if they are attracted by foreign countries. The potential emigration is obtained at about one million for the period 2006 to 2025 .

2. The second group includes new ethnic minorities which appeared after the establishment of independent CIS states. Their migration potential to Russia will depend more on socio-economic and political situation in CIS, as well as the Russian politics. Using a standard gravity model, the estimated migration potential is 6.7 millions for the period 2006 to 2025 . Under the higher degree of economic uncertainty in CIS, which is measured in terms of the standard deviation of GDP growth rates across its members, the estimated potential of migration to Russia would be larger (13.18 millions), while policy restrictions towards immigration in Russia would reduce the estimated potential to 3.23 millions.

3. The third group concerns emigration potential from CIS to Western Europe. The assessment of this potential emigration flow is based on the estimation results reported in Fertig (2001), with the underlying intuition that long-run migration perspectives will be driven by economic factors. The potential emigration from CIS to Germany and Western Europe for economic reasons is equal to 1.26 million and 2.18 millions, respectively, for the period from 2006 to 2025.

Migration flows from CIS countries are thus carefully estimated on economic, demographic and political factors that distinguish our work from traditional projections relying more on informed judgements than on systematic modeling.

Net migration from other regions (North Africa and Eastern Europe) after 2005 are relatively steady and predictable. Thus, we simply calibrate our migration flows to match the UN projections with migrations until 2025. Given the long run feature of INGENUE 2, we need to make some assumptions on migration flows far in the future. Between 2030 and 2100, we keep emigration rates constant at their 2025 values so that migrations flows only evolve with the number of young workers in emigration area. After 2100, migration flows progressively reduce and are nil in 2150 in order for the population to converge towards a stationary level. Table 2 gives the dynamics of net migration flows until 2050. We have to underline here 
that migration flows extrapolations beyond 15 years are not reasonable. Thus, long run value should be seen as a possible extension to provide some hints rather than real prediction.

Table 2: Net migration flows by regions until 2050 (in thousand)

\begin{tabular}{lcccccc}
\hline & $\mathbf{2 0 0 0 - 2 0 0 5}$ & $\mathbf{2 0 0 6 - 2 0 1 0}$ & $\mathbf{2 0 1 1 - 2 0 1 5}$ & $\mathbf{2 0 1 6 - 2 0 2 0}$ & $\mathbf{2 0 2 6 - 2 0 3 0}$ & $\mathbf{2 0 4 6 - 2 0 5 0}$ \\
\hline Western Europe & 0 & 256.1 & 235.1 & 226.0 & 204.9 & 199.9 \\
\hline Mediterranean World & 0 & -178.6 & -147.6 & -153.6 & -159.3 & -175.8 \\
- North Africa & 0 & -113.3 & -101.8 & -101.8 & -97.3 & -102.0 \\
- CIS Middle East Countries & 0 & -65.3 & -45.8 & -51.8 & -62.1 & -73.8 \\
\hline South Asian World & 0 & -64.7 & -50.8 & -50.3 & -51.6 & -54.8 \\
\hline Eastern Europe & 0 & -49.9 & -45.4 & -45.4 & -42.5 & -36.8 \\
$\quad$ - Inflows & 0 & 24.7 & 24.7 & 24.7 & 20.8 & 18.0 \\
$\quad$ - Outflows & 0 & -74.6 & -70.1 & -70.1 & -63.3 & -54.8 \\
\hline Slavic World & 0 & 37.0 & 8.7 & 23.3 & 48.6 & 67.6 \\
$\quad$ - Inflows & 0 & 107.8 & 70.7 & 80.2 & 93.4 & 106.0 \\
$\quad$ - Outflows & 0 & -70.8 & -62.1 & -56.9 & -44.8 & -38.4 \\
\hline \hline Sources : Docquier and Marfouk (2005), Salt (2005), United-Nations (2004), World Bank (2006), Uzagalieva (2007); Authors' calculations
\end{tabular}

\subsection{Results of the migration scenario}

The results of our comprehensive migration scenario are compared to the baseline with no migration. The effects of the shock on the main demographic and macroeconomic variables are presented in Figure 6(expressed in percentage point deviation from the baseline).

The introduction of migratory flows from neighborhood countries in our demographic model strongly modifies the international distribution and the age structure of the world population for the concerned regions. Western Europe is the only zone that faces large immigration flows (the "Slavic world" also exhibits the features of an immigration zone on the whole period but to a lower extent) whereas Eastern Europe, South Asian and Mediterranean zones are emigrations zones (Figure 6(a) . Thus, Western Europe and the "Slavic world" have a total population respectively $6.5 \%$ and $2.7 \%$ higher than in the baseline case in 2050 . At the same time, the population of Eastern Europe and "Mediterranean world" is respectively 3.4\% and $2.6 \%$ lower. The South Asian world is barely affected by migration from Kazakhstan and Tajikistan given that these two countries only represent around $1 \%$ of the South Asian world total population in 2005 .

International migrations also modify the age structure of the world population since migrants are assumed to be young workers (aged 20-24). In 2050, the dependency ratio is almost 6.7 points lower than in the baseline case in Western Europe (Figure 6(b)) and 3.4 point lower in "Slavic world". At this horizon, it increases by about 3.9 points in Eastern Europe and by almost 2 points in "Mediterranean world" 12 It follows that the financing of the PAYG pension system is significantly improved (resp. deteriorated) in Western Europe and in "Slavic world" (resp. in sending regions) in line with the dependency ratio evolution. For example, the contribution rate reaches 30.4\% in Western Europe in 2050 (compared to 32\% in the baseline case) because migrants contribute to its financing. However, the net rates of immigration necessary to offset the effect of ageing in the long run are substantially higher than those of our realistic migration scenario.

\footnotetext{
${ }^{12}$ Note that the emigration rates in Eastern Europe and in the "Mediterranean world" are relatively similar. The significant difference on the dependency ratio evolution is explained by the different demographic features between these two regions. The former is much advanced in the ageing process whereas the latter are still characterized by a more sustained growth of its working-age population. The consequences of young workers emigration are thus more pronounced in the Eastern Europe case.
} 
The impact of migratory flows from neighborhood regions on the GDP growth rate is far from being insignificant. The arrival of young workers progressively increases the GDP growth rate in Western Europe. It is more than 0.2 point higher in 2035 and then stabilizes to this gap with the ageing of first migrant cohorts (see Figure 6(g)). The effect on the "Slavic world" GDP growth rate follows the working-age population evolution and is thus less marked than in Western Europe. The mirror effect of the improving economic situation in Western Europe and in "Slavic world" is a deterioration in the regions of emigration, and noticeably in Eastern Europe. Indeed, the magnitude of the deterioration depends on the loss of potential workers relative to the total labor-force in the regions. As previously explained, Eastern Europe suffers the most adverse consequences of emigration as it is a region much advanced in the ageing process and is already suffering from a declining population.

Nevertheless, the level of consumption per capita is less than in the baseline scenario in Western Europe until the very end of the half-century (see Figure 6(h)). The reason lies in the production sector : the inflow of workers reduces capital intensity relative to baseline. Indeed, immigration can be seen as a supply shock on the labor market, thus impacting on the productivity of factors supplied by natives. For a given stock of capital, an increase in labor supply reduces the capital by worker. The marginal productivity of capital is raised and the interest rate as well. Conversely, labor productivity is diminished with a lower capital intensity.

The real wage rate, being a decreasing function of the return on capital on the factor price frontier, is itself on a slower path than in baseline. It follows that relatively to the baseline scenario, consumption (which depends on labor and capital income) is less augmented than total population; hence consumption per capita is lower until 2040. Indeed, compared to the baseline, investment grows faster than saving in Western Europe until 2040. Around 2025, savings gain momentum in Western Europe (see Figure 6(c)) and the interest rate recedes a bit because savings grow faster than investment from 2040. Therefore the growth of consumption per capita relative to baseline turns positive from 2020 onwards and the level overtakes the baseline one in 2040. In the "Slavic world", the level of consumption per capita is always lower than in the baseline given the net savings profile.

The opposite occurs in emigration regions. But the impact is diffused over several regions and mitigated by the size of the labor-force. The fall in the interest rate and the subsequent increase in productivity persists for almost the entire span of the fifty year period. Only Eastern Europe and the Mediterranean exhibit a non-negligible increase in consumption per capita.

The sharp increase of saving in Western Europe (compared to the baseline trajectory) from 2030 is mainly explained by the facts that the first cohorts of migrants are now entering the "high saver" cohorts (aged between 45 and 69). The opposite occurs mainly in Eastern Europe where saving is decreasing substantially from 2030, as a new illustration of the fact that this region suffers the most adverse consequences of emigration as it is much advanced in the ageing process (see Figure 6(c)).

Because of the rise in interest rate in Western Europe compared to the baseline, the saving investment balance in Western Europe stays more in surplus than in the baseline scenario. The current account balance, which was already in surplus in baseline, is therefore more so. It follows from the improvement of the current account balance that Western Europe reinforces its creditor position in the world economy. The ownership ratio rises systematically above baseline (see Figure 6(f)]. The regions of emigration with slightly appreciating exchange rates relative to baseline stay more in deficit and more in debt. 


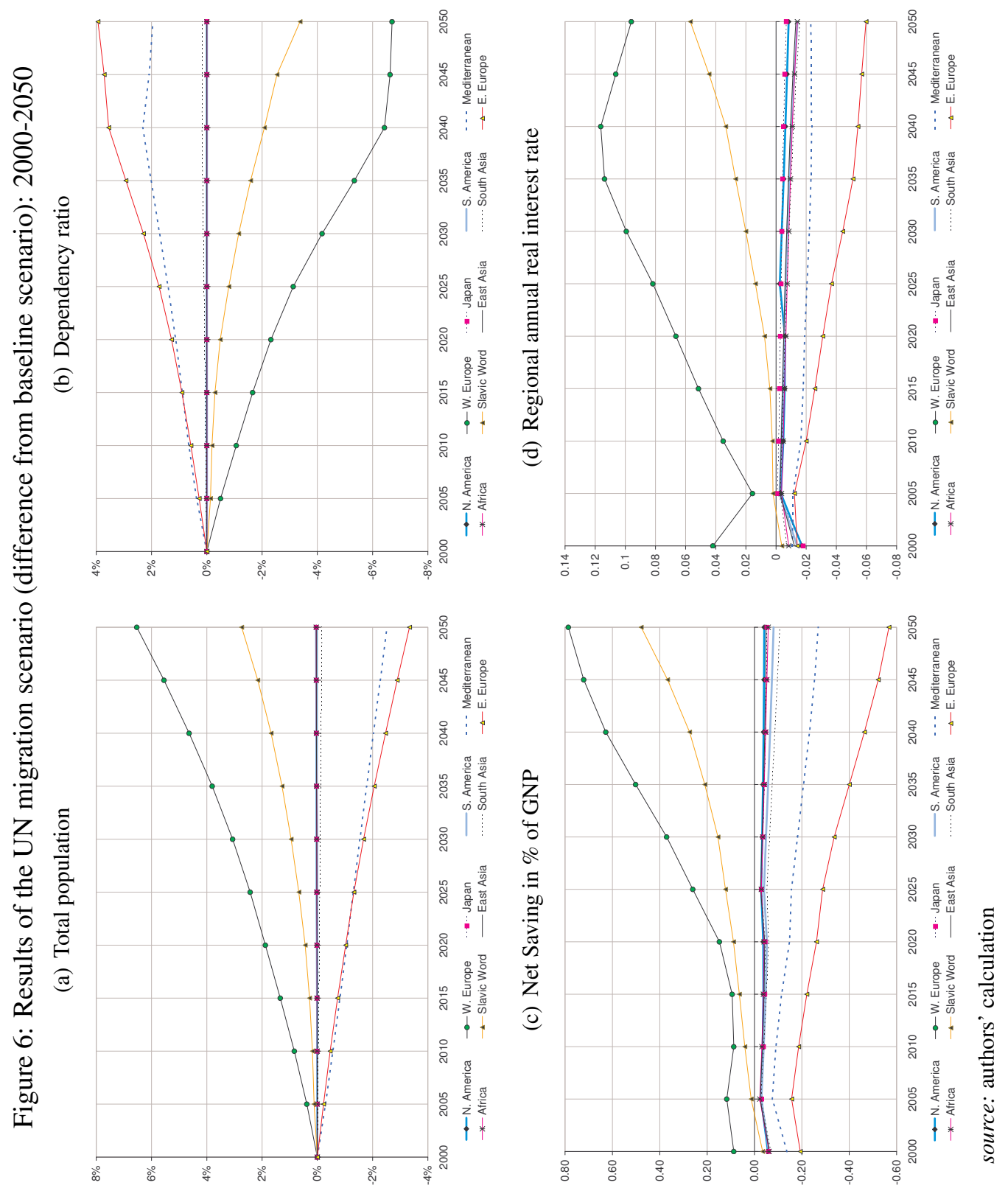




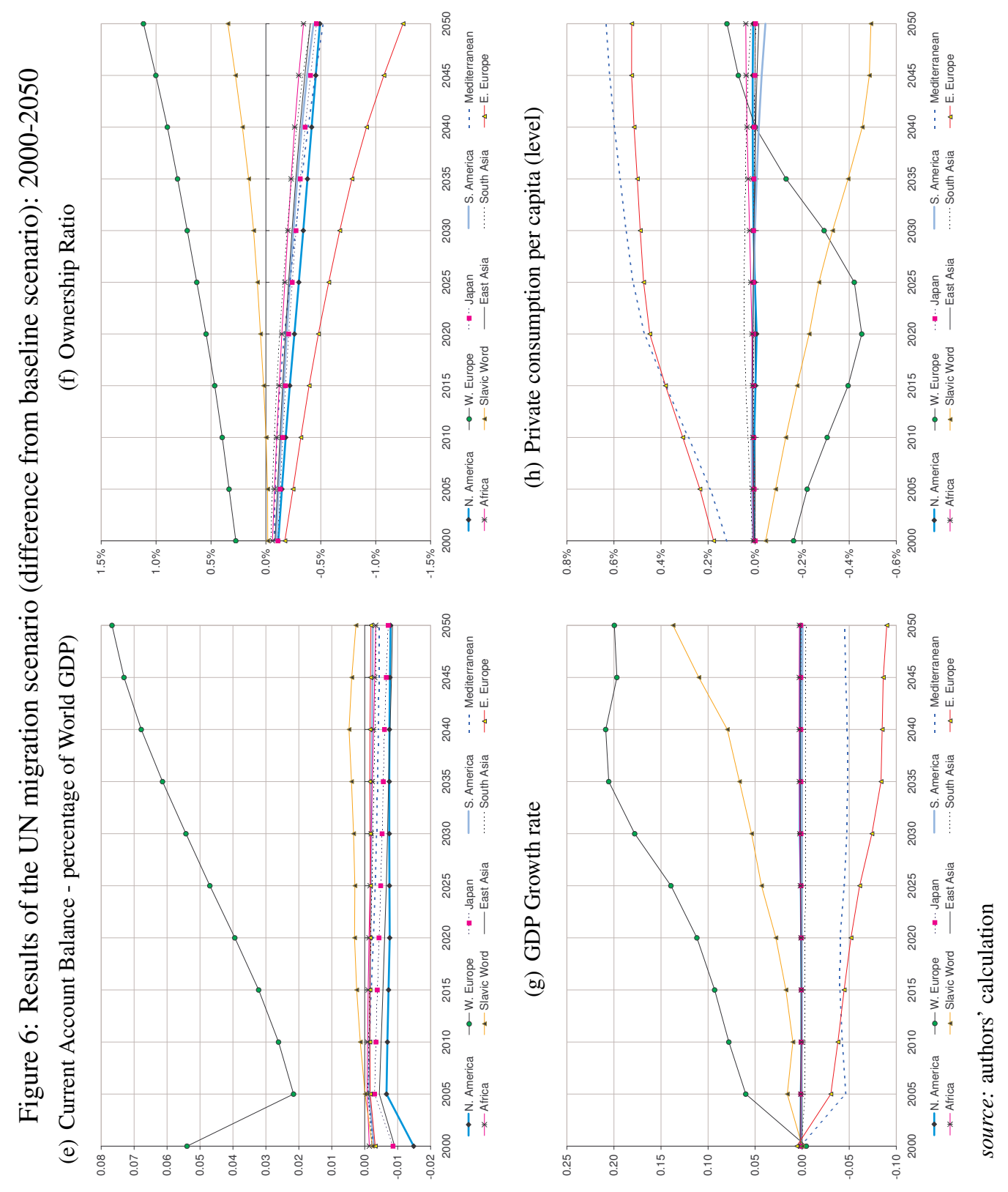




\section{Conclusion}

In this paper we assess the demographic and economic consequences of migration in Europe and the neighborhood countries, using a general equilibrium overlapping generations model. With such a tool, we are able to quantify the demographic consequences of the migrations between neighborhood regions and Western Europe. The general equilibrium OLG model gives some interesting insights into the macroeconomic adjustments of such migration scenarios in the long run. In particular, we show that the financing of the PAYG pension system is substantially improved in the regions receiving the migrants (Western Europe and the "Slavic world" in the migration scenario presented here). Nevertheless, one must note that this realistic migration scenario does not offset the effect of ageing in the regions receiving the migrants: in this regard, pension reforms appear to be necessary in order to deal with the ageing problem that these regions will face in a near future. Concerning the regions losing migrants, the adverse consequences of emigration are more important the more the region is advanced in the ageing process (and is already suffering from a declining population). In this regards, our analysis provides some quantitative results that allow us to compare the consequences of emigration for Eastern Europe and the "Mediterranean world", two regions that are not at the same stage in the ageing process.

We have to underline that our results are sensitive to some assumptions of the model. On the one hand, immigrants are assumed to have exactly the same productivity as the native workers. The skill distribution of immigrants from neighborhood regions suggests that they may be less skilled than the average European worker. On the other hand, the INGENUE 2 model assumes perfect flexibility in the labor and goods markets. Thus, immigration has no impact on unemployment and economic output is continuously at potential.

Furthermore, the general equilibrium multi-regions OLG model that we use have several assumptions that could limit the scope of our analysis. Firstly, the remittances flows (associated with the migrations flows) are not modeled in our framework. Clearly, these flows could be of great importance, from a quantitative point of view, noticeably when we focus on some specific countries (in particular in countries of limited size where the emigration rates are high such as Moldova, Albania, Tajikistan or Armenia with remittances higher than $10 \%$ of GDP). Secondly, the age of migrants is limited to some specific cohort and we do not model return migration. Such demographic assumptions would be quite difficult to include in our multi-regions OLG framework. Despite the shortcomings that we mention, it appears that the main value-added of our analysis is the long term general equilibrium analysis that we propose. 


\section{References}

Aglietta, M., Chateau, J., Fayolle, J., Juillard, M., Cacheux, J. L., Garrec, G. L. \& Touzé, V. (2007), 'Pension reforms in europe: An investigation with a computable olg world model', Economic Modelling 24, 481-505.

Alho, J. \& Borgy, V. (2007), 'Global ageing and macroeconomic consequences of demographic uncertainty in a multi-regional model', Cepii Working Paper 2007-09.

Armington, P. (1969), 'A theory of demand for products distinguished by place of production', IMF Staff Papers (16), 159-78.

Auerbach, A. \& Kotlikoff, L. (1987), Dynamic Fiscal Policy, London : Cambridge University Press.

Backus, D., Kehoe, P. \& Kydland, F. (1995), 'International Business Cycles : Theory and Evidence', in Cooley editors, Frontiers of Business Cycles : Princeton : Princeton University Press pp. p. 331-356.

Barrell, R., FitzGerald, J. \& Riley, R. (2007), 'Eu enlargement and migration: Assessing the macroeconomic impacts’, NIESR Discussion Paper $n^{\circ} 292$.

Brooks, D. (2003), 'Population ageing and global capital flows in parallel universe', IMF Staff Paper 50, p. 200-221.

Börsch-Supan, A., Ludwig, A. \& Winter, A. (2006), 'Aging, pension reform and capital flows', Economica 73, 625-658.

Carrera, S. (2007), 'Building a common policy on labour immigration: Towards a comprehensive and global approach in the eu?', CEPS Working Documents $n^{\circ} 256$.

Chojnicki, X., Docquier, F. \& Ragot, L. (2005), 'L'immigration "choisie" face aux défis économiques du vieillissement démographique', Revue Economique 56, 1359-1384.

Coale, A. \& Demeny, P. (1966), Regional Model Life Tables and Stable Populations, Princeton : Princeton University Press.

Docquier, F. \& Marfouk, A. (2005), International Migration by Educational Attainment (1990-2000) - Release 1.1, Palgrave, chapter 5.

European Commission (2006), 'The global approach to migration one year on: Towards a comprehensive european migration policy', Communication COM 735 final .

Fehr, H., Jokisch, S. \& Kotlikoff, L. (2003), 'The developed world's demographic transition. the roles of capital flows, immigration and policy', NBER Working Paper 10096.

Fehr, H., Jokisch, S. \& Kotlikoff, L. (2004), 'The role of immigration in dealing with the developed world's demographic transition', NBER Working Paper 10512.

Fertig, M. (2001), 'The economic impact of eu-enlargement: Assessing the migration potential', Empirical Economics 26.

Heston, A., Summers, R. \& Aten, B. (2002), Penn World Table Version 6.1, Center for International Comparisons at the University of Pennsylvania (CICUP).

Iakova, D. (2007), 'The macroeconomic effects of migration from the new european union member states to the united kingdom', IMF Working Paper $n^{\circ} 61$. 
Labor migration: macroeconomic and demographic outlook for Europe and

neighborhood regions

IMF (2004), 'How will demographic change affect the global economy?', World Economic Outlook.

Ingenue (2002), 'A Long Term Model for the World Economy', in J.O.Hairault and H.Kempf, editors, Market Imperfections and Macroeconomic Dynamics Boston/London : Kluwer Academic Publishers pp. p. 51-73.

Ingenue (2006), 'The larger europe: Technological convergence and the labour migration', Revue Economique 57(4), 823-850.

Ingenue (2007a), 'Ingenue 2: A long term intertemporal world model for the 21 st century', Mimeo .

Ingenue (2007b), 'Asian catch up, world growth and international capital flows in the xxist century: A prospective analysis with the ingenue 2 model', Cepii Working Paper 200701.

Krueger, D. \& Ludwig, A. (2007), 'On the consequences of demographic change for the rates of returns to capital and the distribution of wealth and welfare', Journal of Monetary Economics 54, 49-87.

Miles, D. (1999), 'Modeling the impact of demographic change upon the economy', Economic Journal 109, p. 1-36.

Modigliani, F. (1986), 'Life cycle, individual thrift, and the wealth of nations, nobel lecture', American Economic Review.

Obstfeld, M. \& Rogoff, K. (1996), Foundations of International Macroeconomics, MIT press editor.

Salt, J. (2005), 'Current trend in international migrations in europe', Council of Europe .

Storesletten, K. (2000), 'Sustaining fiscal policy through immigration', Journal of Political Economy 108(2), 300-323.

United-Nations (2001), World Population Prospects. The 2000 Revision: volume I: Comprehensive Tables, New York: United Nations.

United-Nations (2004), 'World population prospects: The 2004 revision', Department of Economic and Social Affairs, Population Division .

Uzagalieva, A. (2007), 'Labor migration in cis in the context of european integration and changing borders', Enepo report: WP7 .

World Bank (2006), Migration and Remittances: Eastern Europe and the Former Union, The World Bank.

Yaari, M. (1965), 'Uncertain lifetime, life insurance and the theory of the consumer', Review of Econcomic Studies 32, p. 137-150. 


\section{Appendix 1: Regional grouping}

The World is divided in 10 regions according mainly to geographical criteria in the following way. Countries or regions concerned by EU neighborhood migration flows are underlined.

1. "Western Europe" : 'Channel Islands', 'Denmark', 'Finland', 'Iceland', 'Ireland', 'Norway', 'Sweden', 'United Kingdom', 'Greece', 'Italy', 'Malta', 'Portugal', 'Spain', 'Austria', 'Belgium', 'France', 'Germany' (East + West), 'Luxembourg', 'Netherlands', 'Switzerland'.

2. "Eastern Europe" : 'Estonia', 'Latvia', Lithuania', 'Bulgaria', 'Czech Republic', 'Hungary', 'Poland ' Romania', 'Slovakia', 'Slovenia', 'Albania', 'Bosnia and Herzegovina', 'Croatia', 'Former Yugoslav Republic of Macedonia'.

3. "North America" : 'Canada', 'United States of America', 'Australia', 'New Zealand', 'Melanesia', 'Fiji', 'New Caledonia', 'Papua New Guinea', Solomon Islands', 'Vanuatu', 'Micronesia', 'Guam', 'Polynesia', 'French Polynesia', 'Samoa'.

4. "Latin America" : 'Argentina', 'Bolivia', 'Brazil', 'Chile', 'Colombia', 'Ecuador', 'French Guiana', 'Guyana', 'Paraguay', 'Peru', 'Suriname', 'Uruguay', 'Venezuela', 'Belize', 'Costa Rica', 'El Salvador', 'Guatemala', 'Honduras', 'Mexico', 'Nicaragua', 'Panama', 'Bahamas', 'Barbados', 'Cuba', 'Dominican Republic', 'Guadeloupe', 'Haiti', 'Jamaica', 'Martinique', 'Netherlands Antilles', 'Puerto Rico', 'Saint Lucia', 'Trinidad and Tobago'.

\section{Japan}

6. "'Mediterranean world"'" : 'Algeria', 'Egypt', 'Libyan Arab Jamahiriya', 'Morocco', 'Tunisia', 'Western Sahara', 'Cyprus', 'Georgia', 'Iraq', 'Iran', 'Israel', 'Jordan', 'Kyrgyzstan', 'Kuwait', 'Lebanon', 'Occupied Palestinian Territory', 'Oman', 'Qatar', 'Saudi Arabia', 'Syrian Arab Republic', 'Turkey', 'Turkmenistan', 'United Arab Emirates', 'Uzbekistan', 'Yemen'.

7. "Eastern Asian World" : 'China', 'Democratic People's Republic of Korea', 'Mongolia', 'Republic of Korea', 'Brunei Darussalam', 'Cambodia', 'East Timor', 'Lao People's Democratic Republic', 'Myanmar', 'Philippines', 'Singapore', 'Thailand', 'Viet Nam'.

8. "Africa" : 'Burundi', 'Comoros', 'Djibouti', 'Eritrea', 'Ethiopia', 'Kenya', 'Madagascar', 'Malawi', 'Mauritius', 'Mozambique', 'Réunion', 'Rwanda', 'Somalia', 'Uganda', 'Tanzania', 'Zambia', 'Zimbabwe', 'Angola', 'Cameroon', 'Central African Republic', 'Chad', 'Congo', 'Democratic Republic of the Congo', 'Equatorial Guinea', 'Gabon', 'Botswana', 'Lesotho', 'Namibia', 'South Africa', 'Swaziland', 'Benin', 'Burkina Faso', 'Cape Verde', 'Côte d'Ivoire', 'Gambia', 'Ghana', 'Guinea', 'Guinea-Bissau', 'Liberia', 'Mali', 'Mauritania', 'Niger', 'Nigeria', 'Senegal', 'Sudan', 'Sierra Leone', 'Togo'.

9. "'"Slavic world"'" : 'Belarus', 'Russian Federation', 'Ukraine', 'Republic of Moldova',

10. "South Asian World" : 'India', 'Afghanistan', 'Bangladesh', 'Bhutan', 'Maldives', 'Nepal', 'Pakistan', 'Sri Lanka', 'Tajikistan', 'Indonesia', 'Kazakhstan', 'Malaysia'. 


\section{Appendix 2: Description of the model}

In this appendix, we provide a technical presentation of the economic part of the INGENUE 2 model. A complete presentation of the model can be found in Ingenue (2007a).

\section{Households}

Economic choices of households concern consumption/saving and are made with perfect foresight at the beginning of their adult life. Labor supply is assumed to be exogenously given by the age-specific rate of participation to the labor market, noted : $\mathrm{e}_{a}^{z}$. We take International Labor Organization (ILO) data and projections to characterize activity from 1950 until 2015 and we assume that after this date participation rates remain fixed at their 2015 level. Adults can (partially) retire from age $\underline{r}^{z}$ and they may not stay in the labor-force after a legal maximal mandatory retirement age $\bar{r}^{z}$.

The intertemporal preferences of a new entrant in working life, native or migrant, are given by the following life-time utility function over uncertain streams of consumption $c_{a}^{z}$ and leaving a voluntary bequest $H^{z}$ to their children when they reach the age of $T$ (if they survive until this age) 13

$$
\begin{aligned}
U_{a_{0}}^{z}(t) & =\sum_{a=a_{0}}^{20} \rho^{a-a_{0}}\left[\prod_{i=a_{0}}^{a-1} s_{i}^{z}(t+i)\right] \frac{\eta}{\eta-1} c_{a}^{z}\left(t+a-a_{0}\right)^{\frac{\eta-1}{\eta}} \\
& +\rho^{T-a_{0}} \prod_{i=a_{0}}^{T} s_{T}^{z}\left(t+T-a_{0}\right) V\left(H^{z}\left(t+T-a_{0}\right)\right)
\end{aligned}
$$

where $\rho$ is the psychological discount factor, $C_{a}$ is consumption at age $a ; \eta$ is the intertemporal substitution rate and $V(\cdot)$ is the instantaneous utility of bequest : each agent has some felicity from leaving a bequest but it is independent of the future stream of the consumption that his children draw from this bequest (warm glow altruism).

At any given period, the budget constraint is :

$$
\begin{gathered}
\tau_{a}^{z}(t) p_{f}^{z}(t) C_{a}^{z}(t)+p_{f}^{z}(t) S_{a}^{z}(t)=Y_{a}^{z}(t)+p_{f}^{z}(t) S_{a-1}^{z}(t-1) \frac{R^{z}(t)}{s_{a-1}(t-1)} \\
+p_{f}^{z}(t) h_{a}^{z}(t)-p_{f}^{z}(t) H^{z}(t) \Upsilon_{T}(t) \\
Y_{a}^{z}(t)=\left\{\begin{array}{llr}
\zeta_{a}^{z}(t)+\left(1-\theta^{z}(t)\right) w^{z}(t) e_{a}(t) \vartheta_{a} & \text { for } & a<\underline{r}^{a} \\
\left(1-\theta^{z}(t)\right) w^{z}(t) e_{a}(t) \vartheta_{a}+\left(1-e_{a}(t)\right) P_{a}^{z}(t) & \text { for } & \underline{r}^{a} \leq a<\bar{r}^{a} \\
P_{a}^{z}(t) & \text { for } & a \geq \bar{r}^{a}
\end{array}\right.
\end{gathered}
$$

where $S_{a}^{z}$ denotes the stock of assets held by the individual at the end of age $a$ and time $t$, $R^{z}(t) \cdot S_{a}(-1)$ is financial income (domestic real returns on assets holdings times wealth). We assume $S_{a_{0}-1}=0$ and $S_{20} \geq 0$ for all $a \in\left[a_{0}, \ldots, 20\right] . \tau_{a}$ is the age-specific equivalence scale that takes into account costs of child-rearing (see details hereafter), and $Y_{a}$ is the non assets-based net disposal income. $\tau_{a}^{z}(t) p_{f}^{z}(t) C_{a}^{z}(t)$ denotes the total consumption (that is the

\footnotetext{
${ }^{13}$ Usually in these kind of model the age $\mathrm{T}$ is the biological limit to life (here 105 years.) but in order to imply a realistic pattern of inheritance among the children of deceased households, we assume that $\mathrm{T}$ is equal to 80 years old.
} 
consumption of the parents and the one of their children). $p_{f}^{z}(t) S_{a}^{z}(t)$ represents the wealth at the end of date $t . p_{f}^{z}(t)$ denotes the price of the domestic final good (in terms of one foreign goods) so $R^{z}(t)$ is one plus the return to capital income expressed in units of this final good. Due to life uncertainty at the individual level, we assume following Yaari (1965) that there exists perfect annuities markets that pool death risk within the same generation so that the return to capital is "corrected" by the instantaneous survival probability of the generation. Besides children receive inherited assets $h_{a}^{z}(t-1)$ from the voluntary bequests of their parents. People will leave bequest $H^{z}(t)$ to their heirs only at the age of $\mathrm{T}$, so in Equation (3) $\Upsilon_{T}(t)$ is a dummy that will be equal to 1 if $a=T$ and zero in any other case. For full-time active years ( $a \in\left[a_{0}, \underline{r}^{a}\left[\right.\right.$ ), $Y_{a}$ is simply equal to the net labor income after social security taxes (at rate $\theta$ ), where $w$ is the real wage rate per efficient unit of labor at time $t$. When the agent is partly retired ( $a \in\left[\underline{r}^{a}, \bar{r}^{a}\left[\right.\right.$ ), she also receives a pension benefit $P_{a}^{z}$ for the unworked hours. And when she is full-time retired $\left(a \in\left[\bar{r}^{a}, 20\right]\right)$ she only receives the pension benefit. Unless special mention, pension benefits are assumed to be age independent. The $\tau_{a}^{z}$ term is the age-specific equivalence scale. It takes into account the direct and indirect private costs of child-rearing. In order to calculate this relative cost of child-rearing for each cohort, we use the age distribution of children for each parent (from their past fertility behavior) and a constant age equivalence scale of children ${ }^{14} \zeta_{a}^{z}(t)$ is the labor income that children bring to their parents resources during their childhood (calculated in the same spirit as costs of children-rearing).

An agent's earning ability is assumed to be an exogenous function of his age. These skill differences by age are captured by the efficiency parameter $\vartheta_{a}$ which changes with age in a hump-shape way to reflect the evolution of human capital. For simplicity, we assume that this age-efficiency profile is time-invariant and is the same in all regions. We adopt Miles (1999) human capital profile's estimation and $\vartheta_{a}$ is normalized so that $\vartheta_{a_{0}}=1$.

Voluntary bequests are distributed to children according to the fertility calendar of their deceased parents. At the equilibrium the sum of voluntary bequest will be equal to the inheritance received by children. We assume that bequests are distributed equally to all children, i.e. proportional to the proportion of the children born from cohort of age $T$ (according to her past fertility calendar).

In our international context, households can choose the region they want to invest their wealth. The tradeoff between domestic and foreign assets is characterized by :

$$
R^{z}(t)=R^{\star}(t) \frac{p_{f}^{z}(t-1)}{p_{f}^{z}(t)} \quad \text { for all } \mathrm{t}>0
$$

where $R^{\star}(t)$ is the unique world interest factor (in terms of the world numéraire), the condition (4) means that if a region $z$ 'household saves one unit in his domestic asset (capital) it will yield $R^{z}(t)$ in real terms the next period, if he chooses to invest in foreign assets he will receive in real terms $R^{\star}(t) \frac{p_{f}^{z}(t-1)}{p_{f}^{z}(t)}$. The arbitrage condition then leads to return equalization.

\section{The public sector}

The pension $P_{a}^{z}(t)$ paid is a fraction $\kappa(t)$ of the current average (net of tax) wage [1 $\left.\theta^{z}(t)\right] w^{z}(t)$. We assume a time-to-time balanced-budget rule :

\footnotetext{
${ }^{14}$ Trying to get a more detailed structure would entail keeping the distribution of children with respects to their grand-parents and would complicate in an useless way the number of state variables in the system.
} 


$$
\frac{\theta^{z}(t)}{1-\theta^{z}(t)}=\kappa(t) \cdot \frac{\sum_{a \geq \underline{r}^{a}}\left(1-e_{a}(t)\right) L_{a}(t)}{\sum_{a \leq \bar{r}^{a}} e_{a}(t) L_{a}(t)}
$$

In the baseline case, the regional age $\underline{r}^{a}$ of minimum legal retirement age as well as the maximum age $\bar{r}^{a}$ and the ratio $\kappa(t)$ are fixed (at least after year 2000). Payroll tax rates $\theta(t)$ are thus endogenously determined by (5).

\section{Production side}

\section{Intermediate good sector}

Each zone $z$ specializes in the production $Y I^{z}$ of a single intermediate good. Production in period $t$ takes place with a constant return to scale Cobb-Douglas production function using capital stock $K^{z}(t-1)$ installed at the beginning of the period $t$ in the country $z$ and the full domestic labor-force $N^{z}(t), \forall z$ :

$$
Y I^{z}(t)=A I^{z}(t)\left(K^{z}(t-1)\right)^{\alpha}\left(N^{z}(t)\right)^{1-\alpha} \quad 0<\alpha<1
$$

The maximization of the firm value will imply that at the equilibrium $(\forall t)$ :

$$
\begin{aligned}
R^{\star}(t+1) \frac{p_{f}^{z}(t)}{p_{f}^{z}(t+1)}+\delta^{z}(t+1)-1 & =\frac{p_{I}^{z}(t+1)}{p_{f}^{z}(t+1)} \alpha A I^{z}(t+1)\left(k^{z}(t)\right)^{\alpha-1} \\
w^{z}(t) & =p_{I}^{z}(t)(1-\alpha) A I^{z}(t)\left(k^{z}(t-1)\right)^{\alpha}
\end{aligned}
$$

where $p_{I}^{z}$ is the price of the domestic intermediate good, $\delta^{z}(t)$ is the rate of economic depreciation and $k^{z}(t-1)=K^{z}(t-1) / N^{z}(t)$ is the capital-labor ratio.

\section{Final good production sector}

The domestic composite final good of region $z, Y F^{z}$, is produced according to a combination of two intermediate goods: a "domestic" intermediate good in quantities $B^{z}$ and a "World" intermediate good in quantities $M^{z}$, according to the following CES technology, where $\sigma \geq 0$ denotes the elasticity of substitution, $\forall z$ :

$$
Y F^{z}(t)=A F^{z}(t)\left[\left(\omega^{z}\right)^{\frac{1}{\sigma^{z}}}\left(B^{z}(t)\right)^{\frac{\sigma^{z}-1}{\sigma^{z}}}+\left(1-\omega^{z}\right)^{\frac{1}{\sigma^{z}}}\left(M^{z}(t)\right)^{\frac{\sigma^{z}-1}{\sigma^{z}}}\right]^{\frac{\sigma^{z}}{\sigma^{z}-1}}
$$

with $\omega^{z} \in[0,1]$. This CES combination of external and internal good to produce domestic final good is a reminiscence of Armington (1969) aggregator, $A F^{z}(t)$ being total factor productivity. Taking prices as given, the competitive behavior producer determines $B^{z}$ and $M^{z}$ that minimizes current profit: $p_{f}^{z}(t) Y F^{z}(t)-p_{I}^{z}(t) B^{z}(t)-p^{\star}(t) \cdot M^{z}(t)$ subject to 9 , where $p_{I}^{z}$ is the price of the home-specific intermediate good and $p^{\star}$ is the price of the world intermediate good.

\section{The world producer of an homogenous world intermediate good}

In order to simplify the exchanges of intermediate goods between regions of the world, we assume that there exists a fictive world producer that uses all region-specific intermediate goods in quantities $X^{\star, z}$ in order to produce a specific world intermediate good $Y^{\star}$ according to the following CES function : 


$$
Y^{\star}(t)=A^{\star}(t)\left[\sum_{z} \gamma^{z}(t)^{\frac{1}{\mu}} X^{z}(t)^{\frac{\mu-1}{\mu}}\right]^{\frac{\mu}{\mu-1}}
$$

This fictive producer is assumed to act competitively, taking prices as given. Hence, he chooses $\left\{X^{z}(t)\right\}_{z}$, at each period, to maximize its static profit : $p^{\star}(t) Y^{\star}(t)-\sum_{z} p_{I}^{z}(t)$. $X^{z}(t)$, subject to 10 . This yields at the equilibrium the following factor demand function :

$$
X^{z}(t)=\gamma^{z}(t)\left(E^{z}(t)\right)^{-\mu} Y^{\star}(t) A^{\star}(t)^{\mu-1} \quad \text { for all z }
$$

where for convenience $E^{z}(t)=\frac{p_{I}^{z}(t)}{p^{\star}(t)}$ is defined as the terms of trade. It can be shown that at the equilibrium $p^{\star}$ equals to :

$$
p^{\star}=\frac{\left[\sum_{z} \gamma_{z} p_{I}^{z}(t)^{1-\mu}\right]^{\frac{1}{1-\mu}}}{A^{\star}(t)}
$$

\section{A "trick" to model real imperfections on world financial market}

For a world macroeconomic model to be realistic, the world asset capital market has to be imperfect. Because sources of imperfection and asymmetries in financial markets are various and uneasy to model with rigorous micro-foundations in such a large scale model as Ingenue, we adopt the following ad hoc formulation for $\delta^{z}$ the region-specific rate of economic depreciation, with $\varepsilon>0$ :

$$
\delta^{z}(t)=\bar{\delta}^{z}+\left(1-\bar{\delta}^{z}\right) \Delta^{z} \cdot \operatorname{Max}\left(1-\frac{S^{z}(t-1)}{K^{z}(t-1)} ; 0\right)^{\varepsilon} \quad \text { for all } \mathrm{z}
$$

where $S^{z}(t)=\sum_{a=a_{0}}^{19} L_{a}(t) S_{a}(t)$ is the aggregate financial wealth across all cohorts in region $z$ which is equal to the sum of the region capital stock and the net assets on the rest of the world. This equation then indicates that capital invested in a region $z$ depreciates more rapidly than the average when the region is a net debtor to the rest of the world. 


\section{List of working papers released by CEPII ${ }^{1}$}

No

2007-22 Economic Geography, Spatial Dependence and Income Inequality in China

2007-21 Does FDI in Manufacturing Cause FDI in Business Services ? Evidence from French Firm-Level Data

2007-20 Bilateral Trade of Cultural Goods A.C. Disdier, S.H.T. Tai

2007-19 China and India in International Trade: from Laggards to Leaders?

2007-18 How Remote is the Offshoring Threat?

2007-17 Costs and Benefits of Euro Membership: a Counterfactual Analysis

2007-16 Location Decisions and Minimum Wages

2007-15 MIRAGE, Updated Versio of the Model for Trade Policy Analysis Focus on Agriculture and Dynamics

2007-14 Mondialisation des services de la mesure à l'analyse

2007-13 How are wages set in Beijing

2007-12 IMF Quotas at Year 2030

2007-11 FDI and Credit Constraints: Firm Level Evidence in China

\section{Authors}

L. Hering \& S. Poncet

B. Nefussi \& C. Schwellnus

, L. Fontagné \&

T. Mayer

F. Lemoine \&

D. Ünal-Kesenci,

K. Head, T. Mayer \& J. Ries,

E. Dubois, J. Héricourt \&. V. Mignon

I. Méjean,

L Patureau

Y. Decreux \& H. Valin

I. Bensidoun \&

D. Ünal-Kesenci

J. De Sousa \& S. Poncet

A. Bénassy-Quéré, S. Béreau, Y. Decreux, C. Gouel \& S. Poncet

J. Héricourt \& S. Poncet

${ }^{1}$ Working papers are circulated free of charge as far as stocks are available; thank you to send your request to CEPII, Sylvie Hurion, 9, rue Georges-Pitard, 75015 Paris, or by fax : (33) 0153685504 or by e-mail Hurion@cepii.fr. Also available on: Ilwww.cepii.fr. Working papers with * are out of print. They can nevertheless be consulted and downloaded from this website.

1 Les documents de travail sont diffusés gratuitement sur demande dans la mesure des stocks disponibles. Merci d'adresser votre demande au CEPII, Sylvie Hurion, 9, rue Georges-Pitard, 75015 Paris, ou par fax:(33) 0153685504 ou par e-mail Hurion@cepii.fr. Egalement disponibles sur: IIwww.cepii.fr. Les documents de travail comportant * sont épuisés. Ils sont toutefois consultable sur le web CEPII. 
2007-10 Fiscal Policy in Real Time

2007-09 Global Ageing and Macroeconomic Consequences of Demographic Uncertainty in a Multi-regional Model

2007-08 The Effect of Domestic Regulation on Services Trade Revisited

2007-07 The location of domestic and foreign production affiliates by French multinational firms

2007-06 Specialisation across Varieties within Products and North-South Competition

2007-05 Trade Costs and the Home Market Effect

2007-04 The Impact of Regulations on Agricultural Trade: Evidence from SPS and TBT Agreements

2007-03 International Comparisons of Living Standards by Equivalent Incomes

2007-02 Does Risk Aversion Drive Financial Crises? Testing the Predictive Power of Empirical Indicators

2007-01 Asian Catch Up, World Growth and International Capital Flows in the XXIst Century : A Prospective Analysis with the INGENUE 2 Model

2006-27 Current Account Reversals and Long Term Imbalances: Application to the Central and Eastern European Countries

2006-26 On Legal Origins and Brankruptcy Laws: the European Experience (1808-1914)

2006-25 Taux d'intérêt et marchés boursiers : une analyse empirique de l'intégration financière internationale

2006-24 Changing Patterns of Domestic and Cross-Border Fiscal Policy Multipliers in Europe and the US

2006-23 Market Access Impact on Individual Wage: Evidence from China

2006-22 FDI in Chinese Cities: Spillovers and Impact on Growth
J. Cimadomo

J. Alho \& V. Borgy

C. Schwellnus

T.Mayer

I. Méjean

B. Néfussi

L. Fontagné, G. Gaulier \& S. Zignago M. Crozet \& F. Trionfetti

A.-C. Disdier, L. Fontagné \& M. Mimouni

M. Fleurbaey \& G. Gaulier

V. Coudert \& M. Gex

M. Aglietta, V. Borgy, J. Château, M. Juillard, J. Le Cacheux, G. Le Garrec \& V. Touzé

K. Benhima \& O. Havrylchyk

J. Sgard

V. Borgy \& V. Mignon

A. Bénassy-Quéré \& J. Cimadomo

L. Hering \& S. Poncet

N. Madariaga \& S. Poncet 
2006-21 Taux d'intérêt et marchés boursiers : une analyse empirique de l'intégration financière internationale

2006-20 World Consistent Equilibrium Exchange Rates

2006-19 Institutions and Bilateral Asset Holdings

2006-18 Vertical Production Networks: Evidence from France

2006-17 Import Prices, Variety and the Extensive Margin of Trade

2006-16 The Long Term Growth Prospects of the World Economy: Horizon 2050

2006-15 Economic Integration in Asia: Bilateral Free Trade Agreements Versus Asian Single Market

2006-14 Foreign Direct Investment in China: Reward or Remedy?

2006-13 Short-Term Fiscal Spillovers in a Monetary Union

2006-12 Can Firms' Location Decisions Counteract the Balassa-Samuelson Effect?

2006-11 Who's Afraid of Tax Competition? Harmless Tax Competition from the New European Member States

2006-10 A Quantitative Assessment of the Outcome of the Doha Development Agenda

2006-09 Disparities in Pension Financing in Europe: Economic and Financial Consequences

2006-08 Base de données CHELEM-BAL du CEPII

2006-07 Deindustrialisation and the Fear of Relocations in the Industry

2006-06 A Dynamic Perspective for the Reform of the Stability and Gowth Pact

2006-05 China's Emergence and the Reorganisation of Trade Flows in Asia

2006-04 Who Pays China's Bank Restructuring Bill?
V. Borgy \& V. Mignon

A. Bénassy-Quéré, A. Lahrèche-Révil \& V. Mignon

V. Salins

\& A. Bénassy-Quéré

M. Fouquin, L. Nayman \& L. Wagner

G. Gaulier \& I. Méjean

S. Poncet

M. H. Bchir \& M. Fouquin

O. Havrylchyk \& S. Poncet

A. Bénassy-Quéré

I. Méjean

A. Lahrèche-Révil

Y. Decreux

\& L. Fontagné

J. Château

\& X. Chojnicki

H. Boumellassa

\& D. Ünal-Kesenci

H. Boulhol

\& L. Fontagné

C. Deubner

G. Gaulier, F. Lemoine \& D. Ünal-Kesenci

G. Ma 


\section{CEPII \\ DOCUMENTS DE TRAVAIL / WORKING PAPERS}

Si vous souhaitez recevoir des Documents de travail, merci de remplir le coupon-réponse ci-joint et de le retourner à :

Should you wish to receive copies of the CEPII's Working papers, just fill the reply card and return it to:

Sylvie HURION - Publications

CEPII - 9, rue Georges-Pitard - 75740 Paris - Fax : (33) 1.53.68.55.04

sylvie.hurion@cepii.fr

M./Mme / Mr./Mrs

Nom-Prénom / Name-First name

Titre / Title

Service / Department

Organisme / Organisation.

Adresse / Address.

Ville \& CP / City \& post code.

Pays / Country..... Tél.

Your e-mail

Désire recevoir les Document de travail du CEPII $n^{\circ}$ :

Wish to receive the CEPII's Working Papers No:

Souhaite être placé sur la liste de diffusion permanente (pour les bibliothèques)

Wish to be placed on the standing mailing list (for Libraries). 